\title{
Benthic metabolism and nitrogen cycling in a sub-tropical coastal embayment: spatial and seasonal variation and controlling factors
}

\author{
Angus Ferguson ${ }^{1, *}$, Bradley Eyre ${ }^{2}$, Jennita Gay ${ }^{1}$, Nicholas Emtage ${ }^{2}$, Lyndon Brooks ${ }^{2}$ \\ ${ }^{1}$ Aquatic Biogeochemical and Ecological Research, PO Box 409, Brunswick Heads, New South Wales 2483, Australia \\ ${ }^{2}$ Centre for Coastal Biogeochemistry, Southern Cross University, East Lismore, New South Wales 2483, Australia
}

\begin{abstract}
Spatial and seasonal variation in sediment properties, benthic metabolism $\left(\mathrm{O}_{2}\right.$ and $\mathrm{TCO}_{2}$ fluxes) and nitrogen $(\mathrm{N})$ cycling (dinitrogen gas [ $\left.\mathrm{N}_{2}\right]$, dissolved inorganic $\mathrm{N}$ [DIN] and organic $\mathrm{N}$ [DON] fluxes) in western Moreton Bay, Queensland, Australia, were investigated using spatially intensive sediment core incubations. Principal component analysis (PCA) showed that variation in the dataset was best explained by 2 components representing heterotrophic and autotrophic processes respectively. Heterotrophic respiration was most closely associated with sediment chlorophyll $C$, indicating that benthic labile organic carbon (OC) was dominated by phytodetritus (diatoms) and viable phytoplankton cells. The supply of this OC to the sediments was controlled by a combination of phytoplankton biomass and hydrodynamic circulation patterns. Autotrophic benthic production across the study area was closely associated with light attenuation, which varied according to depth and turbidity. DIN fluxes were most closely associated with the autotrophic component, indicating the importance of $\mathrm{N}$ assimilation by benthic microalgae. $\mathrm{N}_{2}$ fluxes were negatively associated with the heterotrophic component, most likely due to the increasing inhibition of coupled nitrificationdenitrification and/or an increase in $\mathrm{N}$ fixation as $\mathrm{OC}$ loading increases. DON fluxes dominated $\mathrm{N}$ fluxes overall and were controlled by autotrophic/heterotrophic DON production and heterotrophic DON consumption. Cluster analysis identified 3 basic states that describe the spatial and temporal variation in benthic processes across western Moreton Bay: reactive nearshore sediments underlying phytoplankton bloom centres (Cluster 1), less reactive sediments further offshore which receive a lesser supply of phytodetritus (Cluster 2) and a new suite of sediment properties, metabolism and $\mathrm{N}$ fluxes at the nearshore sites following a post-flood phytoplankton bloom (Cluster 3).
\end{abstract}

KEY WORDS: Benthic metabolism - Denitrification - $\mathrm{N}$ fixation - Benthic microalgae $\cdot \mathrm{BMA}$. Dissolved organic nitrogen $\cdot$ DON $\cdot$ Spatial $\cdot$ Temporal $\cdot$ Sub-tropical

\section{INTRODUCTION}

Benthic environments are key components of shallow coastal ecosystems due to their role in both autotrophic and heterotrophic production, and in mediating the recycling of nutrients (Boynton et al. 1982, Bonsdorff et al. 1997, Marcus \& Boero 1998, Boon et al. 1999). Sediments are commonly the primary sites for the remineralisation of phytodetritus and allochthonous organic carbon (OC) (Jørgensen 1996), while autotrophic production by benthic microalgae (BMA) can also represent a significant input of $\mathrm{OC}$ to the system (Colijn \& de Jonge 1984, MacIntyre et al. 1996). In turn, the balance between autotrophic and heterotrophic metabolism (net benthic metabolism, or gross production/respiration ratio $[\mathrm{P} / \mathrm{R}]$ ) determines how nutrients will be cycled between the sediments and water column due to competition between assimilatory and dissimilatory pathways (Eyre \& Ferguson 2002, Ferguson et al. 2004a). Of particular concern in coastal environments (where production is commonly nitrogen limited) is the balance among remineralisation of bio-available nitrogen, fixation of nitrogen by diazotrophs, and its removal via denitrification. Recycled 
dissolved inorganic nitrogen (DIN) can support a significant proportion of the primary production within a system and therefore may exacerbate the effects of eutrophication (Ferguson et al. 2004b). In contrast, sediment denitrification is capable of removing a large fraction of the annual nitrogen loading (Eyre \& McKee 2002) and as such may help alleviate nutrient overenrichment.

The importance of benthic processes at the ecosystem scale (for example, the contribution of benthic denitrification in coastal nitrogen budgets) is usually quantified by scaling-up individual rate measurements (Boynton et al. 1995). However, an understanding of the spatial and temporal variability in benthic processes and forcing factors is required to provide reasonable estimates of their contribution to overall ecosystem function. Net metabolism $(\mathrm{P} / \mathrm{R})$ in the benthos varies across broad spatial scales (i.e. hundreds of metres to kilometres) according to factors such as the rate of OC supply, light attenuation, water quality gradients and hydrodynamics (Cadee \& Hegeman 1977, Rizzo \& Wetzel 1985, Kristensen et al. 1997, Asmus et al. 1998). The interaction of these factors gives rise to distinct biofacies within coastal ecosystems, such as heterotrophic depocentres in deeper low energy zones and highly productive autotrophic shoals in shallower areas (Kiørboe 1996). The balance between these biofacies may be altered by nutrient enrichment, with increased water column productivity and phytoplankton biomass leading to greater light attenuation (and decreased benthic productivity) and also greater OC supply to the sediments (and hence greater heterotrophic activity; Cloern 2001). The recycling of nutrients and denitrification efficiency are closely related to metabolism due to a number of positive and negative feedbacks (Eyre \& Ferguson 2005). Hence it is useful to regard both as interdependent components of the system.

Despite their interdependence, few studies have simultaneously examined the spatial and temporal variation in benthic metabolism, benthic nitrogen cycling and denitrification in shallow coastal systems (Yoon \& Benner 1992, Zimmerman \& Benner 1994) and only one spatial study has evaluated the influence of benthic production (i.e. light and dark incubations) on denitrification rates (Dong et al. 2000). Limited spatial replication makes it difficult to properly assess limiting factors for benthic processes at an ecosystem scale. While the study by Dong et al. (2000) provides good information on processes occurring along an estuarine gradient, it was undertaken in a temperate system with very high water column nitrate concentrations which enhanced direct denitrification of water column nitrate and low light regime, thus limiting benthic production. These conditions are distinct from sub-tropical and tropical Australian coastal waters, which are charac- terised by low water column nitrate concentrations, high light regimes and benthic productivity (Eyre 2000, Ferguson et al. 2003). Because benthic production by BMA supplies labile carbon for denitrifiers, competes with denitrifiers for $\mathrm{NO}_{3}{ }^{-}$and is an important control on nitrification, it is expected to influence the spatial variation in denitrification rates in shallow coastal ecosystems. In addition, none of the temperate studies have included dissolved organic nitrogen (DON) fluxes, which dominate benthic nitrogen cycling in tropical coastal systems (Ferguson et al. 2004b, Eyre \& Ferguson 2005).

Moreton Bay is a shallow (6.8 $\mathrm{m}$ average depth) subtropical coastal embayment on the east coast of Australia. For large parts of the year, the bay is subject to highly episodic freshwater inputs, distinct spatial gradients in water quality and sediment nitrogen/carbon concentrations, and euphotic sediments (Dennison \& Abal 1999). These factors are likely to impart strong controls over biogeochemical processes, giving rise to distinct temporal and spatial differences between the sub-tropical Moreton Bay and polar, temperate and wet-tropical systems. In contrast to depositional zones in systems with more pronounced and seasonal freshwater flow where sustained OC supply maintains system heterotrophy (Caffrey et al. 1998), it is likely that OC supply in Moreton Bay will be more episodic and that net metabolism will be significantly influenced by autotrophic processes. The aim of this study was to conceptualise and quantify the spatial and seasonal variations in benthic metabolism and nitrogen cycling across the depositional western fringes of Moreton Bay. We hypothesise that temporal and spatial variations in organic carbon and nutrient cycling may be reasonably predicted according to variations in a suite of key environmental indicators.

\section{MATERIALS AND METHODS}

Study area. Moreton Bay is a semi-enclosed embayment located adjacent to the City of Brisbane in southeast Queensland, Australia (Fig. 1). The bay, with a surface area of approximately $1775 \mathrm{~km}^{2}$, a depth of up to $29 \mathrm{~m}$ (average $=6.8 \mathrm{~m}$ ), and a volume of approximately $1.11 \mathrm{~km}^{3}$, is separated from the Pacific Ocean by Moreton Island and North Stradbroke Island. Moreton Bay exchanges water with the ocean via a $16 \mathrm{~km}$ wide opening to the north, Pumicestone Passage $(0.5 \mathrm{~km})$ to the northwest and 2 minor openings to the east and south: south passage $(3.5 \mathrm{~km})$, and Jumpinpin $(1 \mathrm{~km})$. The bay receives terrestrial runoff from 4 river catchments (Logan, Brisbane, Pine and Caboolture), which have a combined area of $19255 \mathrm{~km}^{2}$. The region receives a summer-dominated rainfall associated with 


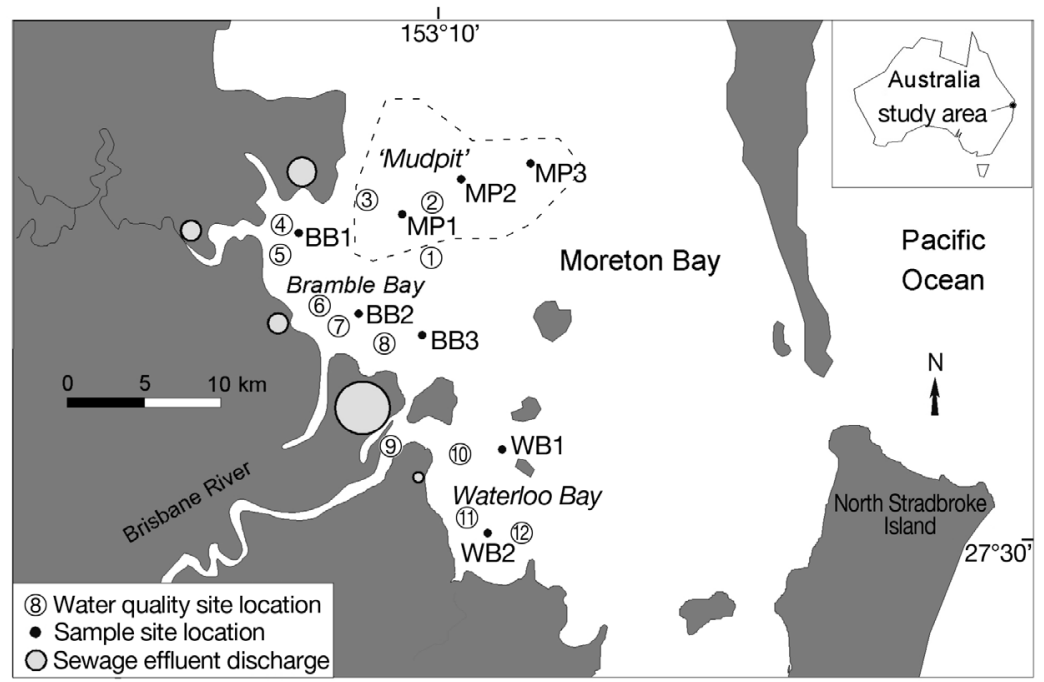

Fig. 1. Study area in Moreton Bay, Queensland, Australia, including the 3 sub-bays and locations of sewage effluent discharge points. Circle size indicates relative effluent loading from that discharge point (Dennison \& Abal 1999). (O) sample sites for benthic processes and (O) water quality collection sites for data in Fig. 2

tropical depressions that move on to the catchment from the north. Moreton Bay receives an annual average rainfall of $1177 \mathrm{~mm}$ (Brisbane International Airport Stn $40223 ; \mathrm{n}=49 \mathrm{yr}$ ) and a mean evaporation that is greater than the mean rainfall (annual pan evaporation $=1961 \mathrm{~mm} ; \mathrm{n}=12 \mathrm{yr})$. Approximately $28 \%$ of the catchment remains undisturbed. The Moreton Bay region is home to approximately 2 million people (Dennison \& Abal 1999).

Water column and sediment nitrogen and carbon concentrations are highest in the poorly flushed western bay, which receives wastewater effluent and urban runoff from the city of Brisbane and diffuse loads from the Brisbane River and Pine River Estuaries. The bay hydrodynamics also concentrates phytodetritus and river sediment in the western bay. In contrast, water column and sediment nitrogen and carbon concentrations are lowest in the eastern bay, which is well flushed with clean oceanic water. There is also a distinct north-south gradient in water column and sediment nitrogen and carbon concentrations along the western margin of the bay; Bramble Bay receives effluent directly from 2 wastewater treatment plants and sediment and nutrient loads from the Brisbane River Estuary, and Waterloo Bay receives only minor direct wastewater effluent or river loads. However, sewage plume mapping using $\delta^{15} \mathrm{~N}$ signatures has shown that sewage plumes may still significantly affect Waterloo Bay during the summer wet season when a southwest counter current exists (Dennison \& Abal 1999).

Sample collection. Six sites in Bramble Bay and 2 sites in Waterloo Bay were sampled in July 2000 (win- ter) and March 2001 (summer; Fig. 1). In Bramble Bay, 3 sites (MP1, MP2, MP3) were sampled along an east-west transect through the 'Mudpit' and 3 sites were sampled along a north-south transect about $1 \mathrm{~km}$ offshore (BB1, BB2, BB3). Sites BB1 and MP1 to MP3 together form a transect from the Redcliffe Sewage Treatment Plant discharge in the western bay to the 'cleaner' waters of the eastern bay (Dennison \& Abal 1999). Sites BB1 to BB3 form a transect between the Redcliffe and Luggage Point Sewage Treatment Plant discharges. One shallow site and one deep site were sampled in Waterloo Bay. Four undisturbed cores were collected at each site (3 for benthic fluxes, 1 for pore waters) using a surface operated hand corer. The plexiglass core liner $(550 \mathrm{~mm}$ long $\times 95 \mathrm{~mm}$ inner diameter) was inserted into the sediment so as to retain a water column of approximately $35 \mathrm{~cm}$ $(2500 \mathrm{ml})$ overlying the sediment, and a gas-tight (on the time scale of the incubations) plexiglass plate was placed on the bottom of the core after it was brought to the surface. An 801 sample of water was also collected from each site, and physicochemical parameters (turbidity, dissolved oxygen, salinity, and temperature) were measured at each sample site using a Horibia U10 multi-probe. Nutrient samples were collected from a depth of $20 \mathrm{~cm}$, with samples for dissolved nutrients filtered through a $0.45 \mu \mathrm{M}$ cellulose acetate filter and transferred to $10 \mathrm{ml}$ acid-rinsed and sample-rinsed polyethylene vials. Samples were stored at $-20^{\circ} \mathrm{C}$ until analysis. Incident radiation was measured using a LiCor 2 pi quantum sensor at the top and bottom of the water column at each of the sample sites to determine light attenuation at the sediment surface.

Benthic flux incubations. After collection, the cores for benthic flux measurements were individually shaded to in situ light conditions $( \pm 5.0 \%)$ using shade cloth, capped with a gas-tight plexiglass plate, placed in a floating cradle in the bay, and equilibrated under in situ light $( \pm 5.0 \%)$ and temperature $\left( \pm 2^{\circ} \mathrm{C}\right)$ conditions for approximately $24 \mathrm{~h}$ to ensure steady-state concentration profiles (Ferguson et al. 2004a). The water in the cores was continuously exchanged (replacement time $=1 \mathrm{~h}$ ) over the $24 \mathrm{~h}$ pre-incubation period from an 801 reservoir of aerated site water, also equilibrated under in situ light $( \pm 5.0 \%)$ and temperature $\left( \pm 2^{\circ} \mathrm{C}\right)$ conditions, to maintain in situ oxygen and nutrient concentrations. All stoppers, replacement water lines and other incubation materials were also carefully pre-incubated to avoid the introduction of 
any new surfaces for $\mathrm{Ar}$ and $\mathrm{N}_{2}$ absorption/desorption. Immediately before the beginning of the flux experiments, the water overlying the sediment cores was again replaced with water from each site. The cores were then sealed gas-tight by a top plexiglass plate with a sample port and a Teflon stir bar mounted on its underside. The cores were incubated under in situ light $( \pm 5.0 \%)$ and temperature $\left( \pm 2^{\circ} \mathrm{C}\right)$ conditions over a $24 \mathrm{~h}$ dark:light cycle starting at sunset. Cores were flushed for $1 \mathrm{~h}$ prior to dawn and resealed at the start of the light incubation. Each core was stirred at a rate just below the threshold for sediment resuspension. This was considered the most appropriate stirring rate because bottom sediments in the bay are regularly resuspended by wind, waves and currents.

Dissolved oxygen concentrations $\left( \pm 0.01 \mathrm{mg} \mathrm{l}^{-1}\right)$ and $\mathrm{pH}( \pm 0.001 \mathrm{pH}$ units) were measured electrochemically, and alkalinity, nutrient and $\mathrm{N}_{2}$ samples were collected at 0, 3, 6 and $13 \mathrm{~h}$ during the dark cycle and at 0 , 4 and $8 \mathrm{~h}$ during the light cycle. The dark incubations were allowed to run for $13 \mathrm{~h}$ to evaluate the sediments' sensitivity to lower dissolved oxygen conditions. If the concentration changes became non-linear, fluxes were only calculated using data from the first $6 \mathrm{~h}$ of the dark incubation during which dissolved oxygen typically only decreased about $20 \%$. The overlying water in each core was replaced with fresh site water at dawn prior to commencement of the light incubation.

Nutrient and alkalinity samples were withdrawn with a plastic syringe and transferred to $10 \mathrm{ml}$ acidrinsed and sample-rinsed polyethylene vials. As a sample was withdrawn, an equal amount was replaced from a gravity-feed reservoir of site water. To minimise the introduction of bubbles, $\mathrm{N}_{2}$ samples were collected in triplicate by allowing water to flow, driven by the reservoir head, directly into $7 \mathrm{ml}$ gas-tight glass vials with glass stoppers filled to overflowing. The replacement water, also equilibrated under in situ light $( \pm 5.0 \%)$ and temperature $\left( \pm 20^{\circ} \mathrm{C}\right)$ conditions, to maintain constant Ar concentrations (Eyre et al. 2002), was withdrawn from a sealed collapsible reservoir bag. All nutrient samples were immediately frozen at $-20^{\circ} \mathrm{C}$ except alkalinity samples, which were kept cold at $4{ }^{\circ} \mathrm{C}$. $\mathrm{N}_{2}$ samples were poisoned with $20 \mu \mathrm{l}$ of $5 \% \mathrm{HgCl}_{2}$ and kept submerged at ambient temperature.

Pore water profiles and sediment solid phase. Sediment cores for pore water samples were sectioned into intervals of $0-1,1-2,3-4,5-6,7-8,9-10,14-15$ and $19-20 \mathrm{~cm}$ in an $\mathrm{N}_{2}$ filled glove bag. After sectioning, each interval was filtered through a GF/C filter and the filtrate was placed in a $10 \mathrm{ml}$ acid-rinsed polyethylene vial which was immediately frozen at $-20^{\circ} \mathrm{C}$. The top $1 \mathrm{~cm}$ of each sediment core was sampled for total organic carbon, total nitrogen and total phosphorus analysis, and the top $2 \mathrm{~mm}$ of each sample core was sampled for chlorophyll analysis. The sediment samples were placed in a $30 \mathrm{ml}$ polyethylene vial and these were immediately frozen at $-20^{\circ} \mathrm{C}$. The chlorophyll samples were immediately extracted with acetone in $10 \mathrm{ml}$ polyethylene vials, wrapped in aluminium foil, and kept cold at $-20^{\circ} \mathrm{C}$ before analysis within $1 \mathrm{wk}$ of collection (Ferguson et al. 2003). The water content of the sediment sample (mean sediment porosity $=0.3$ ) was taken into account by extracting a $1 \mathrm{ml}$ sediment sample in $9 \mathrm{ml}$ of $93 \%$ acetone, giving a final extraction concentration of $90 \%$ acetone.

Sediment oxygen demand (SOD). A $3 \mathrm{ml}$ sample of the top $5 \mathrm{~mm}$ of sediment was taken from each core and placed into a $300 \mathrm{ml}$ glass BOD bottle containing $0.45 \mu \mathrm{m}$ filtered water. The bottle was then capped and shaken then allowed to sit for $30 \mathrm{~min}$. Dissolved oxygen was then measured using a YSI 5000 BOD probe and the bottle was re-capped and placed into a light-proof container and immersed in a constant temperature bath. Three blanks of the filtered water were also incubated to allow for oxygen changes in the water alone. Dissolved oxygen was re-read at 24 and $48 \mathrm{~h}$. A replicate sample of each sediment was also taken and placed into pre-weighed polyethylene vials and stored at $-20^{\circ} \mathrm{C}$ until analysis for bulk density and total organic carbon. The biochemical oxygen demand of each sediment sample was estimated as $\mathrm{mg}$ $\mathrm{O}_{2}$ consumed $\mathrm{g}^{-1}$ dry sediment (Ferguson et al. 2003).

Analytical techniques. All nutrient analyses were carried out colourimetrically using a Lachat Flow Injection Analyser. Analytical errors (in brackets) were determined as the average $\% \mathrm{CV}$ of the triplicates. Because the variance of the analytical procedures propagates additively, the variance associated with the nutrient forms calculated by difference was estimated as the sum of the variances of the 2 measured nutrient forms used in the calculation (Eyre 1995). Analytical accuracy for nutrient analysis was maintained using standard additions of certified laboratory standards in both Milli-Q and low nutrient seawater. Nitrite $\left(\mathrm{NO}_{2}\right)$ was determined using sulphanilamide $(2.8 \%)$, oxidised nitrogen $\left(\mathrm{NO}_{\mathrm{x}}\right)$ was determined by cadmium reduction $(3.6 \%)$, and nitrate $\left(\mathrm{NO}_{3}\right)$ was determined as the difference between $\mathrm{NO}_{\mathrm{x}}$ and $\mathrm{NO}_{2}(6.2 \%)$. Ammonium $\left(\mathrm{NH}_{4}^{+}\right)$was determined using hypochlorite/ phenolate $(5.1 \%)$, and DIN was determined as the sum of $\mathrm{NO}_{\mathrm{x}}$ and $\mathrm{NH}_{4}{ }^{+}(11.3 \%)$. Total dissolved nitrogen (TDN) was determined by persulphate digestion and sulphanilamide (4.1\%) (Valderamma 1981) and DON was determined as TDN minus DIN (15.4\%). Dinitrogen gas $\left(\mathrm{N}_{2}\right)$ was determined from $\mathrm{N}_{2}$ :Ar ratios measured using membrane inlet mass spectrometry with $\mathrm{O}_{2}$ removal (0.01\%) (Eyre et al. 2002). Alkalinity was measured by Gran titration (1\%) (Stumm \& Morgan 1996), and $\mathrm{TCO}_{2}$ was calculated from alkalinity and $\mathrm{pH}$ 
(measured at collection of sample) using the equations given in Almgren et al. (1983) (1.2\%). Chlorophyll was measured using $90 \%$ acetone extraction, and chlorophylls $a, b, c$ and pheophytin were estimated using trichromatic equations given in Jeffrey \& Welschmeyer (1997). Total sediment organic carbon and nitrogen were determined by a LECO CNS analyser with carbonates removed using $2 \mathrm{M} \mathrm{HCl}$ prior to analysis.

Flux calculations. Fluxes across the sediment-water interface were calculated by linear regression of the concentration data (corrected for the addition of replacement water) as a function of incubation time, core water volume and surface area. Only the linear portions of the concentration versus incubation time curve were used in the flux calculations. Dark flux rates were calculated using concentration data from the first period of the incubation and light flux rates were calculated using concentration data from the second period of the incubation.

$$
\begin{aligned}
& \text { Net flux rates }=(\text { dark flux } \times \text { dark hours }+ \text { light flux } \times \\
& \text { light hours }) / 24 \\
& \text { Gross oxygen production (positive, efflux })=\text { Light } \\
& \mathrm{O}_{2} \text { flux }- \text { Dark } \mathrm{O}_{2} \text { flux } \\
& \text { Gross carbon production (negative, uptake })=\text { Light } \\
& \text { TCO }_{2} \text { flux }- \text { Dark TCO } \\
& \text { Benthic P/R }=\text { gross } \mathrm{O}_{2} \text { production } \times \text { daylight hours/ } \\
& \text { dark } \mathrm{O}_{2} \text { flux } \times 24
\end{aligned}
$$

The errors associated with the calculated flux rates are due to the analytical precision of the measured concentration data and the fit of the data to a linear function. The given errors include the standard deviation between the triplicate measurements at each site and the measurement errors of the individual rates.

Statistical analysis. Spatial (between bays) and seasonal differences in sediment properties and fluxes were determined using a 2-way ANOVA with differences between bays determined using Bonferroni and Tamhane post hoc tests (SPSS v.10). Relationships between sediment properties and fluxes were assessed using principal component analysis (SPSS v.10), and scores from the first 3 components were classified by K-means cluster analysis (SPSS v.10). Water quality, sediment properties and metabolic fluxes were compared between clusters by ANOVA, while nitrogen fluxes were compared by cluster, light and season using 3-way ANOVA.

Stoichiometric model. A simple stoichiometric model was constructed to account for the cumulative effects of the different biological and chemical reactions likely to affect $\mathrm{O}_{2}, \mathrm{TCO}_{2}$ and alkalinity (Alk) fluxes during $\mathrm{OC}$ diagenesis. The purpose of the model was to constrain the relative contributions of aerobic and anaerobic respiration and the extent to which sulphide oxidation and calcium carbonate $\left(\mathrm{CaCO}_{3}\right)$ dissolution were occurring. The model predicts the flux ratios of $\mathrm{TCO}_{2}: \mathrm{O}_{2}$, Alk:OC, Alk:O and $\mathrm{TCO}_{2}$ :Alk theoretically occurring within a given respiration scenario (e.g. $25 \%$ aerobic $+75 \%$ anaerobic respiration $+80 \%$ reoxidation of pyrite) assuming the mineralisation of $1 \mathrm{~mol} \mathrm{OC}$. $\mathrm{CaCO}_{3}$ dissolution/precipitation was set as a percentage of OC mineralisation/fixation respectively. $\mathrm{O}_{2}$ production and $\mathrm{TCO}_{2}$ fixation due to benthic productivity were accounted for, and $\mathrm{TCO}_{2}$ fixation due to chemoautotrophic production by sulphide oxidising bacteria was set at a maximum of $35 \%$ of total reduced sulphur oxidation (Howarth 1984). Alkalinity fluxes were corrected for $\mathrm{NH}_{4}{ }^{+}$and $\mathrm{NO}_{3}{ }^{-}$release during aerobic respiration by subtracting measured $\mathrm{NH}_{4}{ }^{+}$fluxes and adding $\mathrm{NO}_{3}{ }^{-}$fluxes, and alkalinity changes due to denitrification were removed by subtracting measured $\mathrm{N}_{2}$ fluxes. Residual corrected alkalinity was then ascribed to sulphate reduction, $\mathrm{CaCO}_{3}$ dissolution/ precipitation and $\mathrm{FeS}_{2}$ formation/oxidation. Anaerobic respiration was assumed to be dominated by sulphate reduction. The percentages of aerobic respiration, anaerobic respiration, sulphide oxidation, and $\mathrm{CaCO}_{3}$ dissolution were varied iteratively to provide a best fit between model estimations and measured data for $\mathrm{TCO}_{2}: \mathrm{O}_{2}, \mathrm{Alk}: \mathrm{OC}, \mathrm{Alk}: \mathrm{O}_{2}$ and $\mathrm{TCO}_{2}$ :Alk in each sample event. Alk:OC is equal to the alkalinity flux $\mathrm{mol}^{-1}$ OC mineralised. The measured Alk:OC was estimated as alkalinity flux: (DINflux $+2 \times \mathrm{N}_{2}$ flux) $\times 106 / 16$, assuming that $\mathrm{OC}$ was Redfield $\mathrm{C}: \mathrm{N}$ and that assimilation of $\mathrm{N}$ during diagenesis was negligible.

\section{RESULTS}

\section{Water quality in western Moreton Bay}

Salinity, turbidity, secchi and chlorophyll a (chl a) concentrations across the study area are presented in Fig. 2, which shows conditions at the time of the winter and summer sampling efforts in addition to annual averages $(n=12)$. Water quality in the deeper Mudpit bay was more stable throughout the study, while Bramble and Waterloo Bays displayed greater ranges of salinity, reflecting the influence of freshwater discharges from the Pine and Brisbane Rivers during the summer wet season and the influence of oceanic water in Waterloo Bay during the winter dry season. Turbidity, light attenuation and chl a concentrations were all highest in Bramble Bay (Sites 4 to 8), and similar in the other bays. Six weeks prior to the summer sampling effort, a flood event occurred in the Brisbane River, immediately followed by a large phytoplankton bloom with elevated chl $a$ and total nitrogen concentrations 

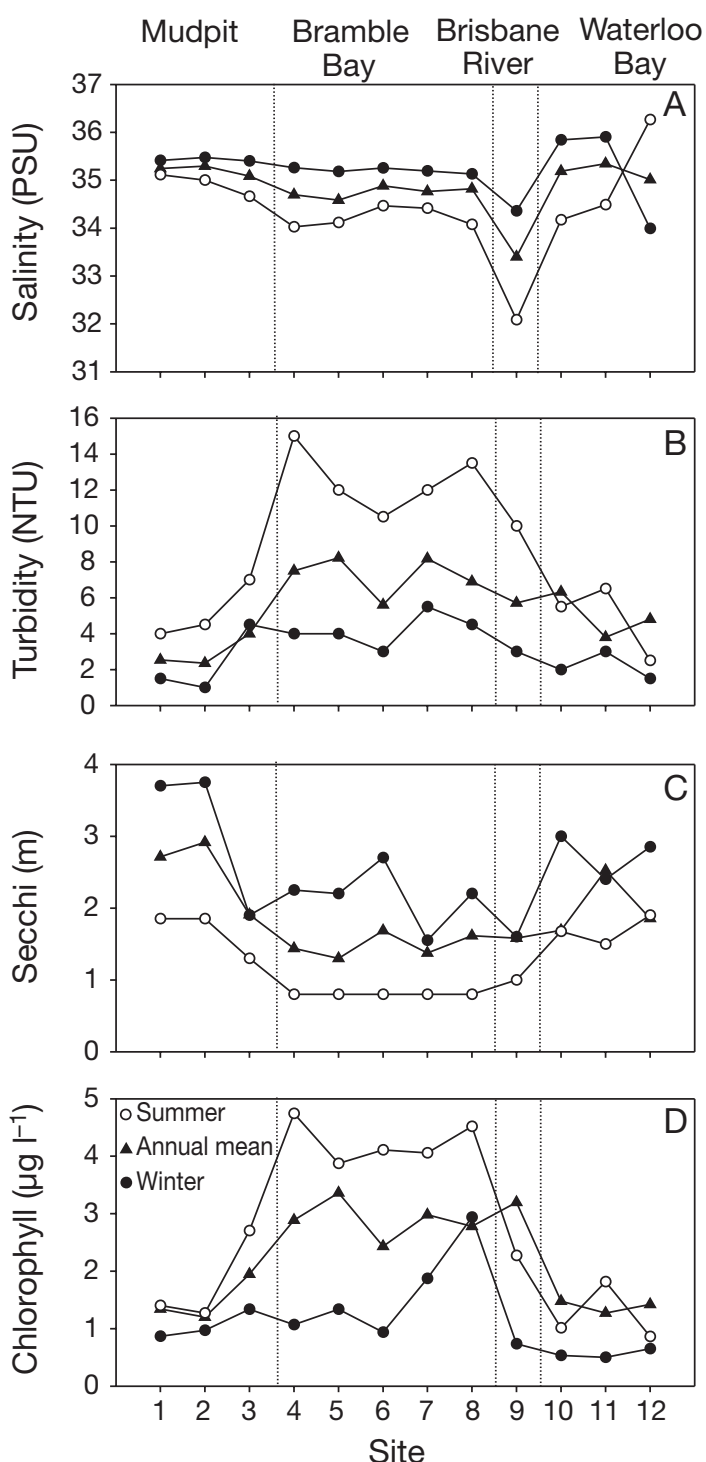

Fig. 2. (A) Salinity, (B) turbidity (NTU: nephelometric turbidity units) (C) secchi depth and (D) chlorophyll $a$ in western Moreton Bay during winter and summer sample campaigns. Annual mean $(\mathrm{n}=12)$ based on monthly samples at each site during the study period (data supplied by the Queensland Environmental Protection Agency as part of the Ecosystem Health Monitoring Program [EHMP] managed by the Moreton Bay Waterways and Catchments Partnership)

across the study area up to 10 times greater than average concentrations (Ecosystem Health Monitoring Program [EHMP] data). Chl a concentrations had returned to just above annual average concentrations within $2 \mathrm{wk}$ prior to the summer sampling effort (Fig. 2).

Water quality and light attenuation at each site measured during the winter and summer sampling efforts are presented in Table 1. Light attenuation was greatest in summer at all sites with the exception of MP1. Ammonium $\left(\mathrm{NH}_{4}{ }^{+}\right)$concentrations were lowest in the
Mudpit and significantly higher in Bramble and Waterloo Bays ( $\mathrm{p}<0.02) . \mathrm{NH}_{4}{ }^{+}$concentrations in Bramble Bay were significantly higher during winter; however, there was no seasonal variation in the other bays. Nitrate $\left(\mathrm{NO}_{3}{ }^{-}\right)$concentrations were also lowest in the Mudpit and significantly higher in the other bays, with the only seasonal variation occurring in Waterloo Bay where $\mathrm{NO}_{3}$ was significantly higher in summer ( $\mathrm{p}<$ 0.01). DON concentrations were highest in the Mudpit and Bramble Bay and increased significantly during summer at all sites $(\mathrm{p}<0.001)$.

\section{Sediment carbon and nitrogen}

The OC, nitrogen and C:N ratios of surface sediments are presented in Fig. 3. OC varied significantly among the bays ( $\mathrm{p}<0.001)$ during the study and there was a significant bay/season interaction. The highest OC contents during winter were found in the Mudpit, followed by Waterloo Bay and Bramble Bay, while in summer the highest OC was found in Waterloo Bay, followed by the Mudpit and Bramble Bay. OC increased significantly in Waterloo Bay $(\mathrm{p}<0.001)$ and decreased significantly in the Mudpit ( $<$ 0.001) during summer, but was seasonally stable in Bramble Bay. Sediment nitrogen content decreased significantly across all bays in summer $(\mathrm{p}<$ 0.001). C:N ratios of surface sediments were significantly different across the bays and seasons ( $p<0.002)$, and there was a significant bay $\times$ season interaction $(\mathrm{p}<$ 0.001). During winter, $C: N$ ratios ranged from near 'Redfield' at the low-carbon near-shore sites to approximately 10 at the high-carbon Mudpit sites. In summer, there was a significant reduction in $\mathrm{C}: \mathrm{N}$ ratios at the Mudpit sites and a significant increase at both the Bramble Bay and Waterloo Bay sites.

\section{Sediment chlorophyll and porewater $\mathrm{NO}_{3}^{-}$}

Chl $a$ and chl $C$ data were not normally distributed due to high chlorophyll contents at one site in Bramble Bay (Site BB1) during winter (Fig. 3). This site was characterised by the lowest $\mathrm{OC}$ and $\mathrm{C}: \mathrm{N}$ ratios in winter and a high density of meiofaunal polychaetes. It is likely that high rates of bioturbation (grazing) at this site resulted in a high turnover of BMA biomass and the tight cycling of sediment carbon. As such, data from this site have been excluded from the ANOVA. There were no spatial or seasonal trends in chl a during the study. Chl $b$ was significantly higher in Bramble Bay $(p<0.001)$; however, there were no clear seasonal trends. There was a significant increase in chl $c$ across all the bays during summer $(p<0.02)$. Porewater $\mathrm{NO}_{3}{ }^{-}$concentrations were significantly less 
Table 1. Depth, light attenuation (\% incident) and water quality at the sample sites in winter (W; July 2000) and summer (S; March 2001)

\begin{tabular}{|c|c|c|c|c|c|c|c|c|c|c|c|c|c|}
\hline & \multirow{2}{*}{$\begin{array}{l}\text { Depth } \\
\text { (m) }\end{array}$} & \multicolumn{2}{|c|}{ Light } & \multicolumn{2}{|c|}{ Salinity } & \multicolumn{2}{|c|}{$\mathrm{NH}_{4}(\mu \mathrm{M})$} & \multicolumn{2}{|c|}{$\mathrm{NO}_{\mathrm{x}}(\mu \mathrm{M})$} & \multicolumn{2}{|c|}{ DON $(\mu \mathrm{M})$} & \multicolumn{2}{|c|}{ DIP $(\mu \mathrm{M})$} \\
\hline & & W & $\mathrm{S}$ & W & S & W & S & W & S & $\mathrm{W}$ & $\mathrm{S}$ & W & $\mathrm{S}$ \\
\hline \multicolumn{14}{|c|}{ Mudpit } \\
\hline MP1 & 4 & 4 & 8 & 36.7 & 35.7 & 1.4 & 1.4 & 0.6 & 0.8 & 4.6 & 11 & 1 & 0.4 \\
\hline MP2 & 7 & 5 & 1 & 36.9 & 36 & 1.6 & 1.3 & 0.6 & 0.4 & 5.2 & 14.1 & 0.5 & 0 \\
\hline MP3 & 7 & 9 & 1 & 36.8 & 36 & 1.2 & 1.2 & 0.8 & 0.8 & 4.9 & 13 & 0.6 & 0.3 \\
\hline \multicolumn{14}{|c|}{ Bramble Bay } \\
\hline BB1 & 2 & 42 & 18 & 35.9 & 34.8 & 8.5 & 1.9 & 1.6 & 0.5 & 6.4 & 9.9 & 3 & 0.3 \\
\hline BB2 & 5 & 2 & 0 & 36.7 & 34.8 & 2 & 2 & 0.4 & 1.4 & 5.1 & 12 & 1 & 0.7 \\
\hline BB3 & 4 & 7 & 1 & 36.6 & 34.5 & 3.2 & 1.8 & 1.4 & 1.1 & 5.5 & 12.4 & 1.4 & 0.4 \\
\hline \multicolumn{14}{|c|}{ Waterloo Bay } \\
\hline WB1 & 5 & 15 & 7 & 36.3 & 35.7 & 1.9 & 3 & 0.5 & 1.7 & 4.9 & 7.2 & 1.2 & 0.8 \\
\hline WB2 & 3 & 30 & 13 & 36.9 & 35.5 & 3.7 & 2.5 & 0.4 & 1.3 & 2.8 & 7.6 & 0.6 & 0.5 \\
\hline
\end{tabular}
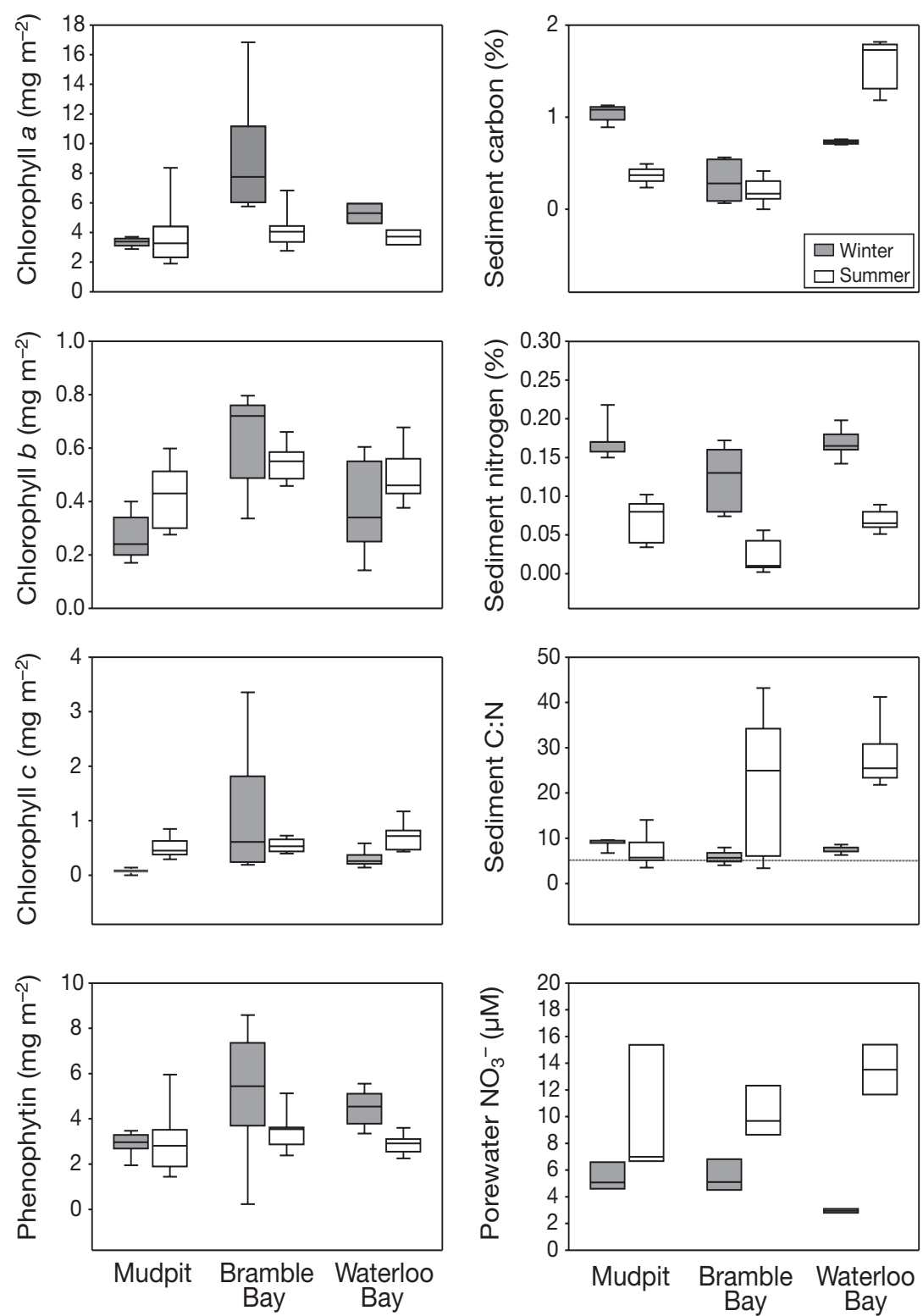

$(\mathrm{p}<0.001)$ in Waterloo Bay than in the other bays during winter. There was a significant increase in porewater $\mathrm{NO}_{3}^{-}$ across all bays during summer ( $\mathrm{p}<$ 0.001), with the largest increase occurring in Waterloo Bay.

\section{Benthic metabolism}

Benthic metabolism and SOD results are presented in Fig. 4. $\mathrm{TCO}_{2}$ fluxes during the dark were significantly higher during summer in all bays ( $p<0.001$ ). Dark $\mathrm{TCO}_{2}$ fluxes tended to be greatest in Bramble Bay (not significant) and were significantly lower in the Mudpit than in the other bays during both summer and winter. Dark $\mathrm{O}_{2}$ uptake tended to be greatest in Bramble Bay during winter and was significantly lower in the Mudpit than the other bays ( $p<0.001)$. $\mathrm{O}_{2}$ uptake in the Mudpit increased significantly during summer ( $\mathrm{p}<0.001)$; in contrast, however, it was lower during summer in both Bramble and Waterloo Bays ( $p<0.001)$. SOD showed clear seasonal and spatial trends, with significant increases from the Mudpit through

Fig. 3. Sediment properties in western Moreton Bay during the study. Data for bays in each season are from triplicate measurements at 3 replicate sites in the Mudpit and Bramble Bay $(\mathrm{n}=9)$ and 2 replicate sites in Waterloo Bay $(n=6)$. Box plots show median (horizontal line) and 25th (lower box) and 75th (upper box) percentiles 


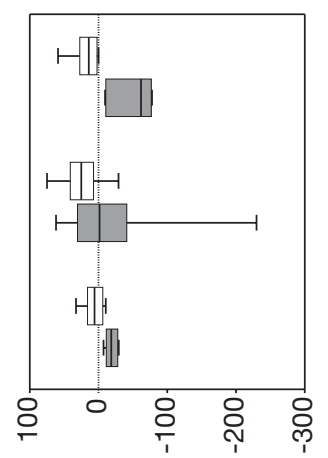

t46!! $\mid+{ }^{\dagger} \mathrm{HN}$

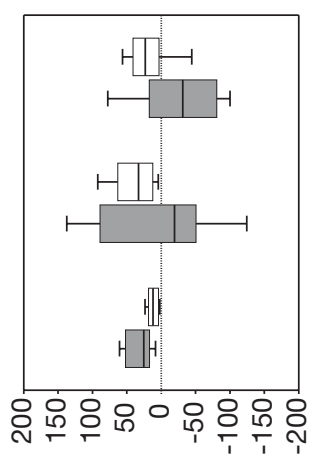

yıер $+{ }^{\dagger} \mathrm{HN}$

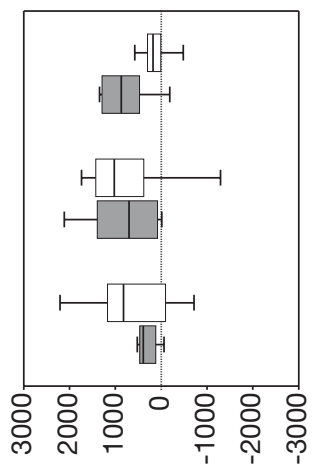

14ढ!! ${ }^{2} \mathrm{O} \perp$

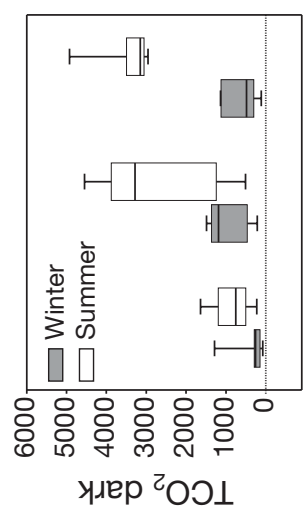

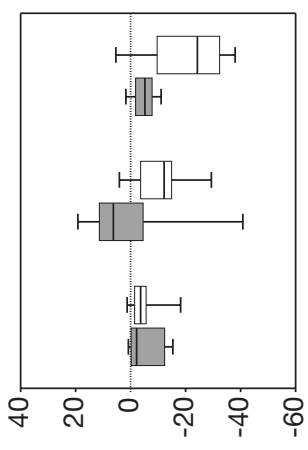

746!! - $-{ }^{\varepsilon} \mathrm{ON}$

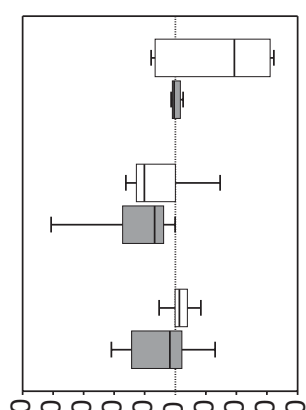

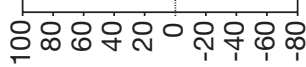

Yнер _E ON

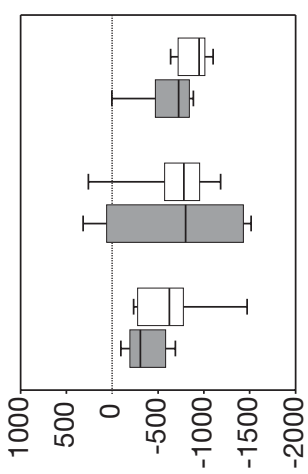

74ढ़!ा ${ }^{2} \mathrm{O}$

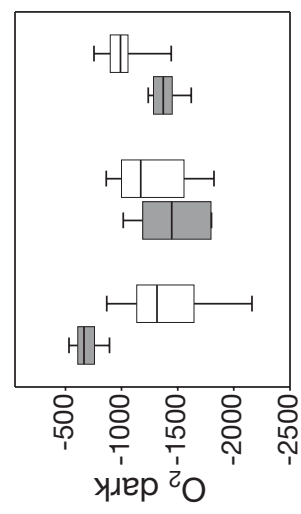

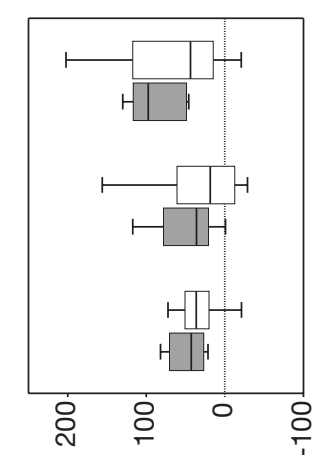

746!! NOO

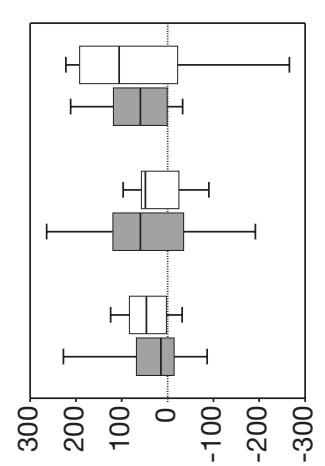

yมер NOO

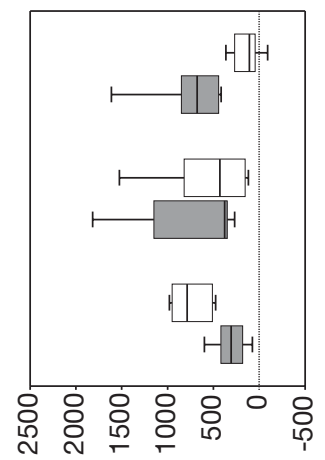

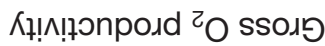

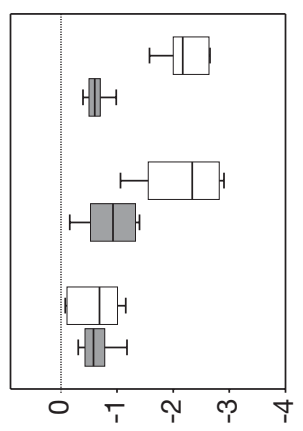

oy

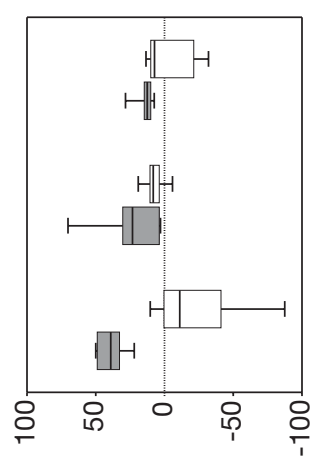

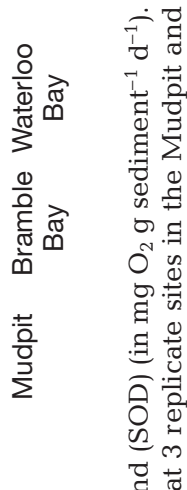

146!! ${ }^{2} \mathrm{~N}$

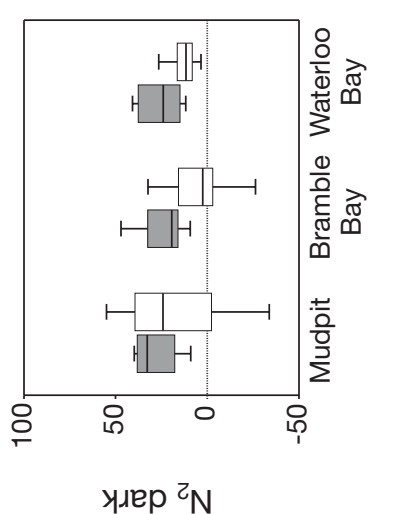

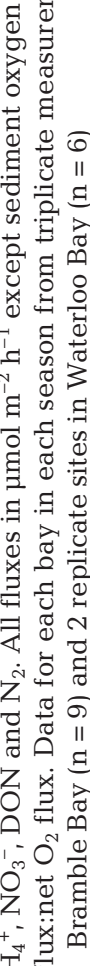

y/d ગ̣!ฺนәg

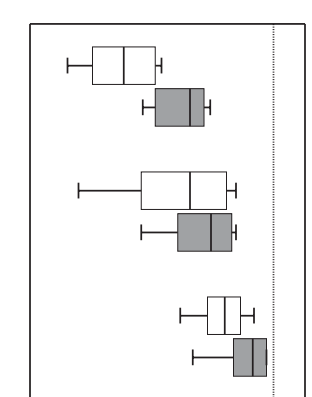

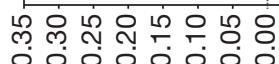

aos

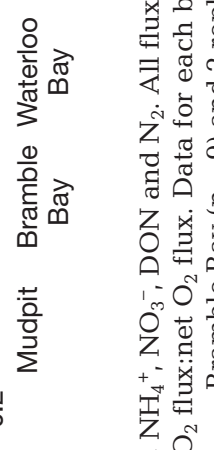

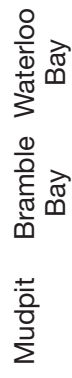

$0^{2} e^{h}$

iิ

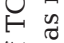

in :

离

䓽

营金

营苟

률

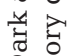

+i.

कृष्ये 
Bramble Bay to Waterloo Bay ( $p<0.001$ ) and a significant increase across all bays during summer.

\section{Benthic productivity}

There were no significant spatial or seasonal trends in light $\mathrm{TCO}_{2}$ and $\mathrm{O}_{2}$ fluxes during the study. Gross benthic productivity estimated from $\mathrm{O}_{2}$ production $\left(\mathrm{O}_{2} \mathrm{GBP}\right)$ was not significantly different between bays. There was a significant increase in $\mathrm{O}_{2} \mathrm{GBP}$ in the Mudpit during summer $(p<0.001)$, while there was a reduction in $\mathrm{O}_{2} \mathrm{GBP}$ for summer in the other bays $(\mathrm{p}<$ 0.001). The 2 estimates of GBP using $\mathrm{O}_{2}$ and $\mathrm{TCO}_{2}$ fluxes $\left(\mathrm{TCO}_{2} \mathrm{GBP}\right.$ data not shown) yielded starkly different and in some cases contradictory results during this study. For example, $\mathrm{O}_{2} \mathrm{GBP}$ was significantly lower in Bramble and Waterloo Bays during summer while the opposite trend was apparent for GBP estimated from $\mathrm{TCO}_{2}$ fluxes. Both estimates of GBP are subject to errors associated with respiration rates used in productivity calculations that may lead to underestimations of GBP; however, these have been previously assumed to be consistent for $\mathrm{O}_{2}$ and $\mathrm{TCO}_{2}$ for which both estimations of GBP agree well (Ferguson et al. 2003).

The biomass and productivity of autotrophic benthic communities (and hence GBP estimated from incubation experiments) will be in part related to the in situ light climate at each site (Schreiber \& Pennock 1995) as well as to factors such as the deposition of viable phytoplankton cells (Eyre \& Ferguson 2005). A comparison of light attenuation (as a proxy for in situ light climate) and GBP showed a significant relationship using $\mathrm{O}_{2} \mathrm{GBP}\left(\mathrm{r}^{2}=0.44, \mathrm{p}<0.001\right)$ and no relationship with $\mathrm{TCO}_{2} \mathrm{GBP}$. This suggests that $\mathrm{O}_{2} \mathrm{GBP}$ is a more reliable measure of benthic production in this system. The rates of $\mathrm{O}_{2} \mathrm{GBP}$ measured during this study (annual mean $565 \pm 468 \mu \mathrm{mol} \mathrm{O} \mathrm{m}^{-2} \mathrm{~h}^{-1}$ ) also compare well with other studies of subtidal sediments of similar depth (e.g. $750 \mu \mathrm{mol} \mathrm{O} \mathrm{O}_{2} \mathrm{~m}^{-2} \mathrm{~h}^{-1}$ (Schreiber \& Pennock 1995), $562 \mu \mathrm{mol} \mathrm{O} \mathrm{m}^{-2} \mathrm{~h}^{-1}$ (Meyercordt \& Meyer-Reil 1999) and light attenuation (e.g. $625 \mu \mathrm{mol} \mathrm{O}_{2} \mathrm{~m}^{-2} \mathrm{~h}^{-1}$ at $<1 \%$ of incident; Cahoon et al. 1993). In contrast, rates of $\mathrm{TCO}_{2} \mathrm{GBP}$ were excessively high (up to $6000 \mu \mathrm{mol}$ $\mathrm{O}_{2} \mathrm{~m}^{-2} \mathrm{~h}^{-1}$ ) for sediments of this depth, suggesting that these rates were unduly influenced by $\mathrm{CaCO}_{3}$ precipitation (Anderson et al. 1986). As such, only $\mathrm{O}_{2}$ GBP estimates have been used in the principal component (PCA) and cluster analyses.

\section{Nutrient fluxes}

Dark and light nutrient fluxes are presented in Fig. 4. Dark ammonium $\left(\mathrm{NH}_{4}{ }^{+}\right)$fluxes ranged from -143 to
$154 \mu \mathrm{mol} \mathrm{m}{ }^{-2} \mathrm{~h}^{-1}$ in winter and from -49 to $105 \mu \mathrm{mol}$ $\mathrm{m}^{-2} \mathrm{~h}^{-1}$ in summer. There were no significant spatial or seasonal trends in dark $\mathrm{NH}_{4}{ }^{+}$fluxes; however, uptake occurred more consistently during winter (primarily in Bramble and Waterloo Bays) and summer was dominated by effluxes. This trend was clearer in light $\mathrm{NH}_{4}{ }^{+}$ fluxes, which displayed a significant increase $(\mathrm{p}<$ 0.001 ) in fluxes (or shift from uptake to efflux) during summer in all bays. Dark nitrate $\left(\mathrm{NO}_{3}\right)$ fluxes ranged from -30 to $98 \mu \mathrm{mol} \mathrm{m}^{-2} \mathrm{~h}^{-1}$ in winter and from -65 to $35 \mu \mathrm{mol} \mathrm{m}{ }^{-2} \mathrm{~h}^{-1}$ in summer. Dark $\mathrm{NO}_{3}$ fluxes were highest (dominated by effluxes) in Bramble Bay, lowest (dominated by sediment uptake) in Waterloo Bay and decreased across all bays during summer. There were no apparent trends in light $\mathrm{NO}_{3}$ fluxes. Dark DON fluxes ranged from -271 to $327 \mu \mathrm{mol} \mathrm{m}^{-2} \mathrm{~h}^{-1}$ in winter and from -293 to $225 \mu \mathrm{mol} \mathrm{m}{ }^{-2} \mathrm{~h}^{-1}$ in summer. DON fluxes were significantly greater during the light $(\mathrm{p}<$ 0.001) during both seasons. There were no significant spatial or seasonal trends in DON fluxes during the study. Dark dinitrogen $\left(\mathrm{N}_{2}\right)$ fluxes ranged from 6 to $51 \mu \mathrm{mol} \mathrm{m}{ }^{-2} \mathrm{~h}^{-1}$ in winter and from -68 to $23 \mu \mathrm{mol} \mathrm{m}{ }^{-2}$ $\mathrm{h}^{-1}$ in summer. There were significant decreases $(\mathrm{p}<$ 0.001) in dark $\mathrm{N}_{2}$ fluxes during summer for all bays, but the only significant decreases in $\mathrm{N}_{2}$ light fluxes in summer were at the Mudpit sites. There were no significant differences in $\mathrm{N}_{2}$ fluxes across the bays in either season.

\section{Principal component analysis}

Relationships among sediment properties, metabolism and nutrient fluxes were analysed using PCA to elucidate the primary factors driving benthic metabolism and nutrient cycling across western Moreton Bay (Table 2). Net metabolism (both $\mathrm{TCO}_{2}$ flux and P/R) and SOD were most strongly associated with chl $C$ (component 1). Chl $C$ is associated with diatoms (i.e. bacillariophytes) (Brotas \& Plante-Cuny 1998) as well as dinoflagellates and chrysophytes. Phytoplankton blooms in western Moreton Bay are dominated by diatoms with a lesser abundance of dinoflagellates (Dennison \& Abal 1999), which suggests that component 1 is indicative of phytodetritus and its impact on labile organic carbon in the sediment and heterotrophic metabolism. $\mathrm{N}_{2}$ flux is negatively associated with component 1 , which indicates that net denitrification decreases as heterotrophic activity increases, concomitant with an increase in $\mathrm{NH}_{4}$ effluxes. DON flux is also negatively associated with heterotrophic activity. Component 2 is positively associated with $\mathrm{O}_{2}$ gross primary production, and $\mathrm{O}_{2}$ respiration and negatively associated with carbon and respiratory quotients. Component 3 is most closely associated with P/R (neg- 
Table 2. Principal component analysis of sediment properties and key fluxes for western Moreton Bay. Associations of parameters with a component are considered significant if the score for that parameter exceeds 0.6. RQ: respiratory quotient; SOD: sediment oxygen demand; P/R: production/ respiration ratio

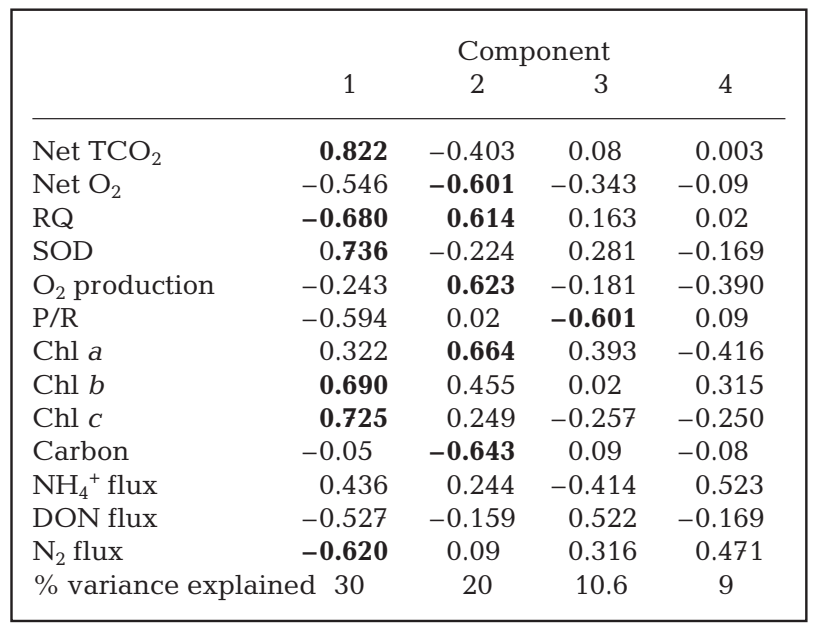

ative) and DON flux (positive), which indicates heterotrophic release of DON compounds.

\section{Cluster analysis}

Scores for each of the first 3 components (Table 2) have been classified according to K-means cluster analysis, yielding 3 clusters. Bays and seasons were classified according to their representation in clusters, and the environmental conditions, sediment quality and fluxes characterising each cluster are presented in Table 3. Clusters represent functional zones that integrate $\mathrm{OC}$ content and quality, and metabolic and nutrient-cycling status, thereby providing useful units for comparing spatial and temporal trends in western Moreton Bay. During winter, the Mudpit sites were represented by Cluster 2, while the Bramble and Waterloo Bay sites were associated with Cluster 1. Cluster 1 had significantly higher light availability, chlorophyll concentrations, $\mathrm{O}_{2}$ respiration, SOD and benthic productivity $(\mathrm{p}<0.001)$. Despite the higher productivity in Cluster $1, \mathrm{P} / \mathrm{R}$ was higher in Cluster 2 due to lower labile $\mathrm{OC}$ and respiration. Net $\mathrm{N}_{2}$ fluxes were significantly higher in Cluster 2 ( $p<0.001)$. During summer, the Mud- pit and the northernmost Bramble Bay site (BB1) were associated with Cluster 1, while the southern Bramble Bay sites and all of Waterloo Bay sites were exclusively associated with Cluster 3. This shift from Cluster 1 to Cluster 3 between winter and summer in Bramble and Waterloo Bays was associated with significant reductions in water column salinity, $\mathrm{pH}$, light availability, benthic productivity and net $\mathrm{N}_{2}$ flux, and significant increases in carbon, sediment $\mathrm{C}: \mathrm{N}, \mathrm{SOD}, \mathrm{TCO}_{2}$ respiration and respiratory quotients $(p<0.001)$.

\section{Respiratory quotients}

Respiratory quotients $\left(\mathrm{RQ}=\right.$ net $\mathrm{TCO}_{2}: \mathrm{O}_{2}$ flux $)$ in all bays during winter and the Mudpit during summer (i.e. Clusters 1 and 2) were less than 1, indicating $\mathrm{O}_{2}$ fluxes in excess of the expected stoichiometry for aerobic respiration and/or anaerobic respiration, coupled with the efficient oxidation of reduced equivalents (Fig. 5). The percentage of aerobic respiration in shallow (2 to $20 \mathrm{~m}$ depth) coastal sediments should be approximately 1:1 (varying according to factors such as the rate of $\mathrm{OC}$ supply and bioturbation) (Jørgensen 1982, Mackin \& Swider 1989). Minimal burial of reduced sulphur in most coastal systems indicates 80 to $95 \%$ re-oxidation (Howarth 1984). Assuming that no $\mathrm{CaCO}_{3}$ dissolution occurs and that the primary reduced sulphur species undergoing formation/oxidation is pyrite $\left(\mathrm{FeS}_{2}\right)$, the above respiration scenario should yield a $\mathrm{CO}_{2}: \mathrm{O}_{2}: \mathrm{Alk}$

Table 3. Mean values for water quality, sediment properties and benthic fluxes characterising each cluster. Significant differences $(p<0.01)$ were determined by ANOVA (Bonferroni post hoc tests)

\begin{tabular}{|c|c|c|c|c|}
\hline & \multicolumn{3}{|c|}{ Cluster } & \multirow[t]{2}{*}{ Sig. diff } \\
\hline & 1 & 2 & 3 & \\
\hline Light (\% incident) & 14 & 6 & 6 & \\
\hline Salinity & 36.63 & 37.65 & 35.18 & $2>1>3$ \\
\hline Water column DON $(\mu \mathrm{M})$ & 8.08 & 5.43 & 9.55 & $3=1>2$ \\
\hline Carbon $(\%)$ & 0.41 & 0.95 & 1.00 & $3=2>1$ \\
\hline $\mathrm{C}: \mathrm{N}$ & 8.48 & 8.37 & 24.42 & $3>2=1$ \\
\hline Chlorophyll $c\left(\mathrm{mg} \mathrm{m}^{-2}\right)$ & 0.46 & 0.10 & 0.61 & $3=1>2$ \\
\hline $\mathrm{SOD}\left(\mathrm{mg} \mathrm{O}_{2} \mathrm{gm}^{-1}\right)$ & 0.10 & 0.05 & 0.21 & $3>1>2$ \\
\hline Net alkalinity flux ( $\mu \mathrm{eq} \mathrm{m}^{-2} \mathrm{~h}^{-1}$ ) & 284 & -169 & 50 & $1>2=3$ \\
\hline Net $\mathrm{TCO}_{2}$ flux $\left(\mu \mathrm{mol} \mathrm{m}{ }^{-2} \mathrm{~h}^{-1}\right)$ & 747 & 512 & 2230 & $3>2=1$ \\
\hline Net $\mathrm{O}_{2}$ flux $\left(\mu \mathrm{mol} \mathrm{m}{ }^{-2} \mathrm{~h}^{-1}\right)$ & -1089 & -663 & -1009 & $3>1=2$ \\
\hline $\mathrm{O}_{2}$ production $\left(\mu \mathrm{mol} \mathrm{m} \mathrm{m}^{-2} \mathrm{~h}^{-1}\right)$ & 817 & 381 & 213 & $1>2=3$ \\
\hline $\mathrm{P} / \mathrm{R}$ & 0.20 & 0.27 & 0.07 & $1=2>3$ \\
\hline RQ & -0.61 & -0.63 & -2.29 & $1=2>3$ \\
\hline Porewater $\mathrm{NO}_{3}(\mu \mathrm{M})$ & 7.13 & 5.42 & 12.73 & $3>2=1$ \\
\hline Net DIN flux $\left(\mu \mathrm{mol} \mathrm{m} \mathrm{m}^{-2} \mathrm{~h}^{-1}\right)$ & 4.22 & 5.36 & 27.83 & - \\
\hline Net DON flux $\left(\mu \mathrm{mol} \mathrm{m}{ }^{-2} \mathrm{~h}^{-1}\right)$ & 39.52 & 42.08 & -13.04 & - \\
\hline Net $\mathrm{N}_{2}$ flux $\left(\mu \mathrm{mol} \mathrm{m} \mathrm{m}^{-2} \mathrm{~h}^{-1}\right)$ & 16.61 & 30.58 & 4.92 & $2>1>3$ \\
\hline Flux $C: N$ & 3.35 & 4.38 & 113.19 & $3>1=2$ \\
\hline Denitrification efficiency (\%) & 71 & 83 & 35 & - \\
\hline
\end{tabular}



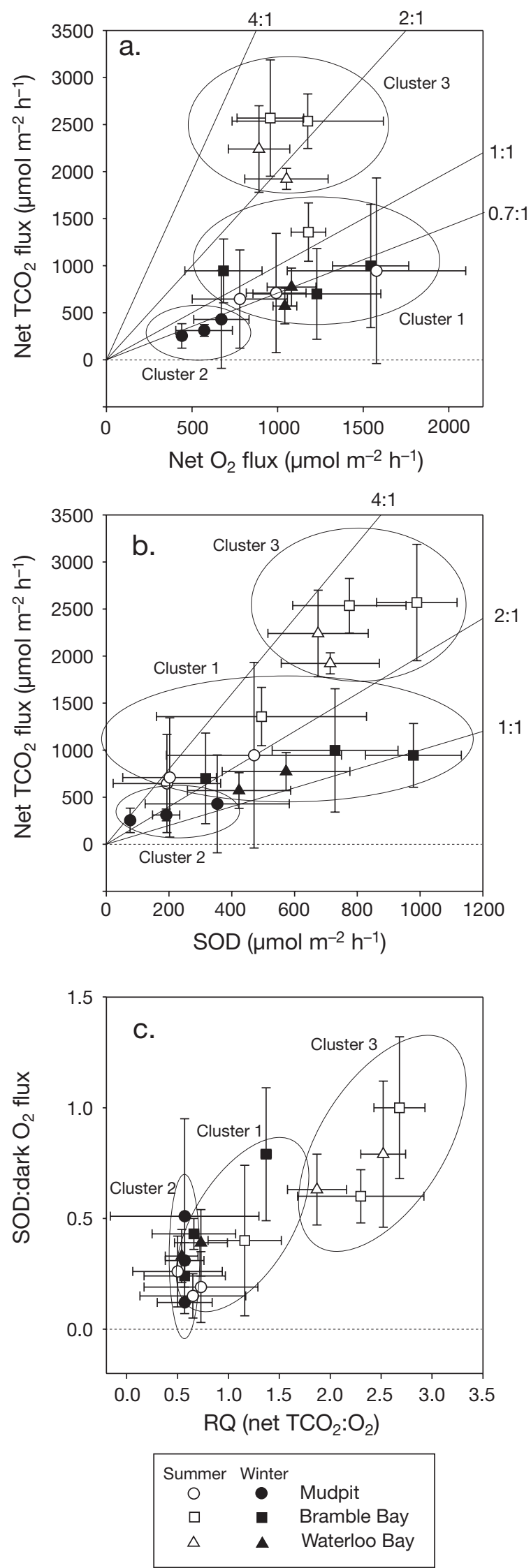

flux ratio of 1:-1.4:-0.95 $\mathrm{mol}^{-1} \mathrm{OC}$ mineralised (i.e. RQ $=0.72$ ). Most Cluster 1 and 2 sites plot close to or slightly below this RQ (Fig. 5); however, $\mathrm{CO}_{2}: \mathrm{O}_{2}$ :Alk flux ratios at Cluster 1 sites (Table 4) suggest that aerobic respiration may increase to $70 \%$ of total respiration and that $\mathrm{CaCO}_{3}$ dissolution may be much more important ( $>80 \%$ of potential). This scenario yields a much higher RQ (1.69; Fig. 5); however, RQs are significantly reduced if potential $\mathrm{TCO}_{2}$ fixation by photoautotrophs and chemolithoautotrophs (e.g. sulphide oxidising bacteria) is taken into account. Assuming a $\mathrm{TCO}_{2}$ fixation efficiency of $37 \%$ in chemolithotrophs (Howarth 1984) and $100 \%$ in BMA, RQs may be as low as 0.67 at the most autotrophic site (BB1 during winter). Even lower RQs indicate that net $\mathrm{O}_{2}$ consumption in Clusters 1 and 2 may have been influenced by the oxidation of stored reduced equivalents from periods of higher respiration in the preceding autumn wet season. During summer, RQs in Bramble and Waterloo Bays (Cluster 3) were between 1 and 4, suggesting possible anaerobic respiration with storage of reduced equivalents. $\mathrm{CO}_{2}: \mathrm{O}_{2}$ :Alk flux ratios in Cluster 3 sites indicated that anaerobic respiration may have increased to $90 \%$ of total and that re-oxidation may have dropped to $40 \%$, indicating a significant storage of reduced equivalents (Table 4).

A comparison between $\mathrm{TCO}_{2}$ fluxes and SOD yielded RQs for winter sites within the expected stoichiometry range for aerobic respiration, assuming no $\mathrm{CaCO}_{3}$ dissolution (1:1) and maximal dissolution (2:1) (Stumm \& Morgan 1996) (Fig. 5). Our SOD method is dominated by aerobic respiration due to the small sample suspended in oxic water, and the impacts of bioturbation on $\mathrm{O}_{2}$ fluxes are excluded. As such, the SOD provides a proxy measure of labile carbon in the surface sediments. An estimation of bio-irrigation can be made by comparing dark $\mathrm{O}_{2}$ flux to the SOD for the same sediments (i.e. SOD: $\mathrm{O}_{2}$ flux $=1$, indicating no bio-irrigation; $\mathrm{SOD}: \mathrm{O}_{2}$ flux $<1$, indicating enhanced $\mathrm{O}_{2}$ flux due to bio-irrigation; Kristensen et al. 1991, Ferguson et al. 2003). Fig. 5 shows potentially high bioirrigation in western Moreton Bay associated with lower RQs and efficient re-oxidation (Clusters 1 and 2), and decreasing bio-irrigation estimated in sediments

Fig. 5. (a) $\mathrm{Net}^{\mathrm{TCO}_{2}}$ fluxes compared with net $\mathrm{O}_{2}$ fluxes (mean $\pm \mathrm{SD}$ ) at each of the study sites in summer and winter. In winter most sites plot below the 1:1 line, indicating enhanced $\mathrm{O}_{2}$ fluxes relative to $\mathrm{TCO}_{2}$ fluxes and suggesting the impacts of bio-irrigation. (b) $\mathrm{Net} \mathrm{TCO}_{2}$ fluxes compared with sediment oxygen demand (SOD) for the same sediments. SOD measure excludes $\mathrm{O}_{2}$ consumption due to bio-irrigation. (c) Net respiratory quotients (RQ) compared with $\mathrm{SOD}: \mathrm{O}_{2}$ flux. SOD: $\mathrm{O}_{2}$ flux $<1$ indicates likely enhancement of $\mathrm{O}_{2}$ fluxes due to bio-irrigation 
Table 4. Mean stoichiometry of metabolic fluxes in the 3 clusters. Aerobic respiration (expressed as a percentage of total respiration), re-oxidation efficiency and $\mathrm{CaCO}_{3}$ dissolution efficiency were calculated iteratively to give the best agreement between measured and predicted stoichiometric ratios

\begin{tabular}{|ccccccc|}
\hline & $\mathrm{RQ}$ & $\mathrm{Alk}: \mathrm{O}_{2}$ & $\mathrm{CO}_{2}$ :Alk & $\begin{array}{c}\% \text { aerobic } \\
\text { respiration }\end{array}$ & $\begin{array}{c}\% \text { re- } \\
\text { oxidation }\end{array}$ & $\begin{array}{c}\% \mathrm{CaCO}_{3} \\
\text { dissolution }\end{array}$ \\
\hline Cluster 1 & -0.61 & -0.17 & 5.56 & 58 & 74 & 79 \\
Cluster 2 & -0.63 & 0.26 & -3.17 & 67 & 95 & 10 \\
Cluster 3 & -2.34 & -0.05 & -147.63 & 23 & 38 & 43 \\
\hline
\end{tabular}

where RQs suggested anaerobic respiration and greater storage of reduced equivalents (Cluster 3).

\section{Controls on $\mathbf{N}$ fluxes}

In order to separate the overlying influences of OC quality and net metabolism on nitrogen cycling in western Moreton Bay, a more specific PCA model was constructed to focus on the major driving factors for autotrophy and heterotrophy: light availability and productivity for autotrophy, and labile carbon content (given by SOD) for heterotrophy (Table 5). SOD was included in preference to $\mathrm{O}_{2}$ and $\mathrm{TCO}_{2}$ fluxes as a measure of heterotrophic potential due to the cryptic nature of these fluxes (see above). This model yields 3 components, with the first clearly associated with autotrophy, the second with heterotrophy, and the third associated with a negative interaction between net DON fluxes and P/R (similar to Component 3 in Table 2).

A comparison of light and dark nitrogen fluxes between seasons and clusters was made using 3-way ANOVA. There was a significant reduction in efflux or conversion to uptake during the light for both the $\mathrm{NH}_{4}{ }^{+}$ $(\mathrm{p}<0.04)$ and the $\mathrm{NO}_{\mathrm{x}}$ fluxes $(\mathrm{p}<0.001)$, with this trend significantly greater for $\mathrm{NO}_{\mathrm{x}}$ fluxes in Cluster 3

Table 5. Principal component analysis of the primary indicators and drivers of autotrophic and heterotrophic processes and nitrogen fluxes

\begin{tabular}{|lccr|}
\hline & \multicolumn{3}{c|}{ Component } \\
& 1 & 2 & 3 \\
\hline Light attenuation & $\mathbf{0 . 8 6 0}$ & 0.226 & -0.142 \\
Chl $c$ & $\mathbf{0 . 6 5 5}$ & 0.518 & 0.282 \\
SOD & -0.328 & $\mathbf{0 . 7 1 8}$ & -0.334 \\
$\mathrm{O}_{2}$ production & $\mathbf{0 . 7 7 2}$ & 0.116 & 0.343 \\
P/R & $\mathbf{0 . 6 3 3}$ & -0.410 & 0.422 \\
Net DIN flux & $\mathbf{0 . 7 1 6}$ & -0.125 & 0.424 \\
Net DON flux & 0.584 & -0.168 & $\mathbf{- 0 . 6 1 3}$ \\
Net N flux $_{\text {\% variance explained }}$ & 0.157 & $\mathbf{- 0 . 7 6 6}$ & -0.274 \\
& 39 & 21 & 14 \\
\hline
\end{tabular}

(as indicated by a significant interaction between cluster and light: $\mathrm{p}<$ 0.002). There was a strong negative relationship between light availability and the magnitude of net DIN fluxes across the study area $\left(\mathrm{r}^{2}=0.71, \mathrm{p}<\right.$ 0.01). The opposite trend occurred for DON fluxes, with significantly greater effluxes during the light ( $\mathrm{p}<0.001)$. There was no significant light effect on $\mathrm{N}_{2}$ fluxes.

\section{DISCUSSION}

\section{Benthic metabolism and organic matter}

The oxygen respiration rates measured for western Moreton Bay during this study (study mean $1200 \mu \mathrm{mol}$ $\mathrm{O}_{2} \mathrm{~m}^{-2} \mathrm{~h}^{-1}$ ) were similar to unvegetated sediments of the same OC content in the nearby Brunswick and Sandon sub-tropical estuaries (Ferguson et al. 2003). However, in comparison to respiration rates reported for northern hemisphere coastal embayments at similar latitudes, rates in Moreton Bay were slightly lower (e.g. annual means: $2344 \mu \mathrm{mol} \mathrm{O}_{2} \mathrm{~m}^{-2} \mathrm{~h}^{-1}$ in Ochlockonee Bay [Seitzinger 1987], $1432 \mu \mathrm{mol} \mathrm{O} \mathrm{m}^{-2} \mathrm{~h}^{-1}$ in Mobile Bay [Cowan et al. 1996], and $2682 \mu \mathrm{mol} \mathrm{O} \mathrm{O}^{-2}$ $\mathrm{h}^{-1}$ in Fourleague Bay [Miller-Way et al. 1994]). This discrepancy may be explained in part by higher sediment $\mathrm{OC}$ and chlorophyll concentrations at sites measured in the northern hemisphere systems, due primarily to greater freshwater inputs and nutrient loadings to these systems.

RQs (=net $\mathrm{TCO}_{2}: \mathrm{O}_{2}$ flux) and estimated bio-irrigation in all bays during winter and the Mudpit during summer (i.e. Clusters 1 and 2, Fig. 5) indicated efficient recycling of reduced equivalents and a high turnover of $\mathrm{OC}$ by the benthic community. During summer, however, RQs in Bramble and Waterloo Bays (Cluster 3) suggested possible anaerobic respiration with storage of reduced equivalents (Table 4). Anaerobic respiration, most likely dominated by sulphate reduction, may be expected following the post-flood phytoplankton bloom, which would have greatly increased the OC supply to sediments prior to the summer sampling effort. Rapid respiration increases in response to such events can lead to the storage of reduced equivalents in the sediment profile causing imbalances in $\mathrm{TCO}_{2}$ and $\mathrm{O}_{2}$ fluxes (Sampou \& Oviatt 1991). This $\mathrm{O}_{2}$ debt can be rebalanced after OC supply wanes and re-oxidation becomes more efficient (i.e. RQs < 1) (Ferguson et al. 2003, Eyre \& Ferguson 2005), a condition which prevailed during winter across the study area and in the Mudpit during sum- 
mer (Clusters 1 and 2). RQs $<1$ are common in nearby sub-tropical systems (Ferguson et al. 2003, Eyre \& Ferguson 2005) due to the relatively short-lived and episodic nature of major nutrient and OC inputs to these systems. In contrast, in temperate systems RQs > 1 are common due to more constant and higher OC inputs (Dollar et al. 1991, Giblin et al. 1997, Hopkinson et al. 1999).

\section{Sources of organic carbon}

PCA revealed that benthic metabolism across western Moreton Bay (indicated by $\mathrm{TCO}_{2}$ flux and SOD) was most strongly associated with indicators of microalgal biomass (chlorophylls) and not TOC (Table 2). This suggests that labile OC is primarily derived from fresh algal material as opposed to allochthonous OC. During winter, sediment C:N ratios across all bays ranged from 4 to 10 , suggesting a predominance of microbial OC, assuming $\mathrm{C}: \mathrm{N}>17$ for terrestrial material (Lancelot \& Billen 1985). Fig. 6 shows that peaks in $\mathrm{chl} C$, gross primary production, respiration and SOD all occurred at a Redfield C:N ratio of $\sim 6.6$, indicating that benthic metabolism across western Moreton Bay during winter and the Mudpit during summer (i.e. Clusters 1 and 2) was directly associated with microalgal material and was highest in association with fresh algal cells. The reactivity of sediment OC drops rapidly as C:N approaches 10 at the Mudpit sites (Cluster 2), suggesting that $\mathrm{OC}$ in this bay is dominated by detrital microalgal material (see also Table 2). Hydrodynamic modelling of water circulation in Moreton Bay (Dennison \& Abal 1999) shows that tidal velocities are minimal and residence times are longest in Bramble Bay, resulting in an accumulation of sewage nutrients and hence phytoplankton biomass in this area. In western Moreton Bay, residual circulation (net water movement over a $7 \mathrm{~d}$ period) is northward during winter; therefore, it is likely that a certain amount of phytoplankton biomass from Bramble Bay is transported to the Mudpit, where it is deposited as phytodetritus.

The significant increase in benthic metabolism across the study area during summer was most likely

Fig. 6. Indicators of $(a, b)$ benthic respiration, (c) benthic productivity, and (d) microalgal biomass plotted as a function of sediment C:N. Polynomial curves fitted to the data peak near the theoretical Redfield ratio (6.6). These comparisons are intended to show the influence of fresh microalgal material on benthic metabolism. Cluster 3 sites not included due to significant influence on sediment $\mathrm{OC}$ by high $\mathrm{C}: \mathrm{N}$ allochthonous material
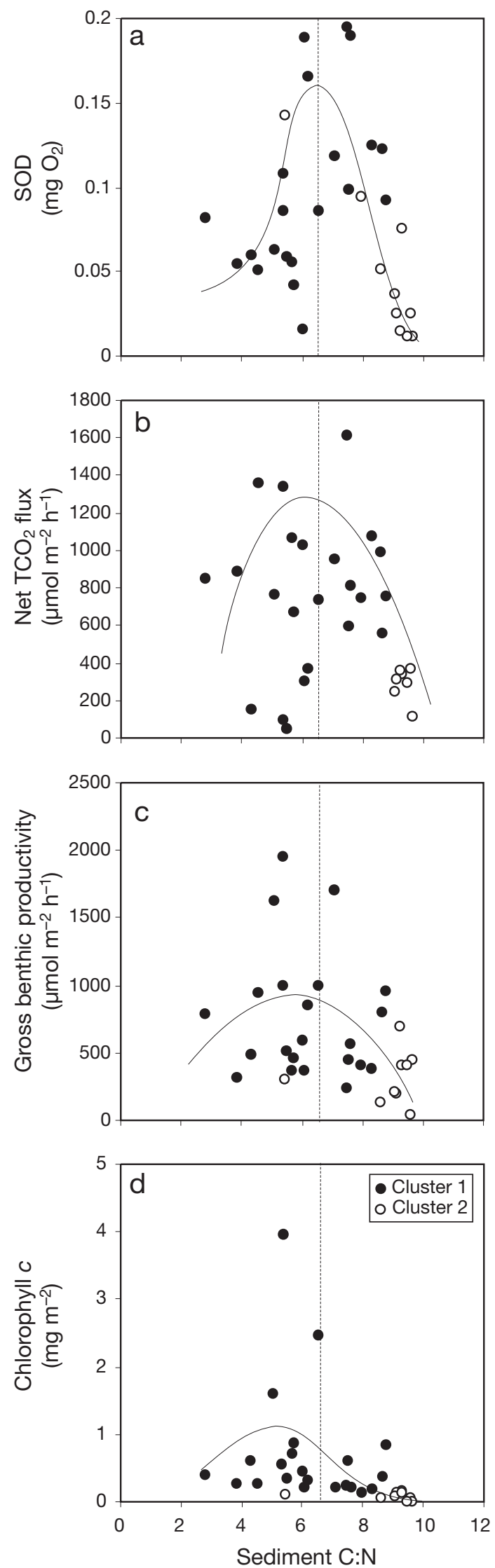
driven by increased temperatures and a combination of allochthonous OC inputs from the February flood event (as indicated by elevated C:N ratios in Bramble and Waterloo Bays) and phytodetritus from the postflood bloom. The Mudpit became associated with Cluster 1 during summer (i.e. higher sediment chlorophylls, productivity and respiration as demonstrated in Table 3), probably due to the increased deposition of phytodetritus and viable algae during and following the post-flood bloom (Eyre \& Ferguson 2005). In summer, Bramble and Waterloo Bays became associated with Cluster 3, characterised by increases in both OC (only significant in Waterloo Bay) and sediment $\mathrm{C}: \mathrm{N}$, which suggests allochthonous $\mathrm{OC}$, and increases in chl $c$ from diatomaceous phytodetritus. A large proportion of allochthonous material is likely to be refractory (Billen \& Lancelot 1988) and therefore unlikely to have a great influence on benthic metabolism, in contrast to the much more labile phytodetritus from the post-flood bloom. This is confirmed by the absence of any positive correlation between $\mathrm{OC}$ and respiration (Components 1 and 2; Table 2). While there was a significant increase in chl $C$ across the study area during summer, other sediment chlorophyll pigments showed no significant increase. It is possible that the spectrophotometric method used for sediment chloropigments failed to adequately measure the degradation products associated with the deposited post-flood bloom. For example, bioturbation by deposit-feeding macrofauna can enhance the conversion of chl $a$ to phaeophorbide while having little effect on chl $C$ concentrations (Bianchi et al. 1988). This may have resulted in underestimations of chl $a$ in the present study during summer.

Another significant feature during summer was high DON concentrations in the water column across the study area (Table 1). These compounds may be associated with catchment runoff (Seitzinger \& Sanders 1997), cell lysis (Newell et al. 1981) or extracellular excretion by autotrophs (Goto et al. 1999, Koster \& Meyer-Reil 2001). DON production has been shown to be associated with phytoplankton blooms in nearby shallow sub-tropical systems (Ferguson et al. 2004b) as well as in temperate systems (Glibert 1993, Bronk et al. 1998). High DON concentrations during the summer sampling effort are therefore likely to be due to a combination of residual catchment inputs and production during the post-flood bloom. DON has also been shown to be a potential energy source for benthic respiration and, in particular, sulphate reduction (Guldberg et al. 2002); therefore, the high concentrations during summer may account for some of the increased summer respiration, especially in Cluster 3 sites, where RQs suggested a predominance of sulphate reduction.

\section{Nitrogen cycling}

A comparison of carbon mineralisation rates (estimated here by net $\mathrm{TCO}_{2}$ fluxes) and nitrogen mineralisation (estimated from DIN and $\mathrm{N}_{2}$ fluxes) demonstrates no clear relationships across all sites during either season (Fig. 7). This can be attributed to the differing controls over DIN and $\mathrm{N}_{2}$ fluxes, including the $\mathrm{C}: \mathrm{N}$ of the OC substrates, $\mathrm{N}$ assimilation by autotrophic/heterotrophic microbes, and the impacts of infauna. During winter, the Mudpit sites and 2 Bramble Bay sites regenerate $\mathrm{N}$ close to the expected stoichiometry for the mineralisation of Redfield material. This may be expected due to the predominance of microalgae-derived material during this season (Redfield 1934, Berelson et al. 1998, Eyre \& Ferguson 2002). Cluster 2 sites displayed fluxes with even lower C:N, potentially due to the impacts of bio-irrigation, which may enhance the flux of $\mathrm{NH}_{4}{ }^{+}$from excretion (Yamada \& Kayama 1987, Bird et al. 1999). Consistent with bioirrigation were low RQs and low $\mathrm{SOD}: \mathrm{O}_{2}$ flux ratios at cluster 2 sites (Fig. 5). Alternatively, low C:N ratios of fluxes may arise from the decomposition of bacterial biomass, which typically has a C:N of less than 5 (Wheeler \& Kirchman 1986). This scenario would sug-

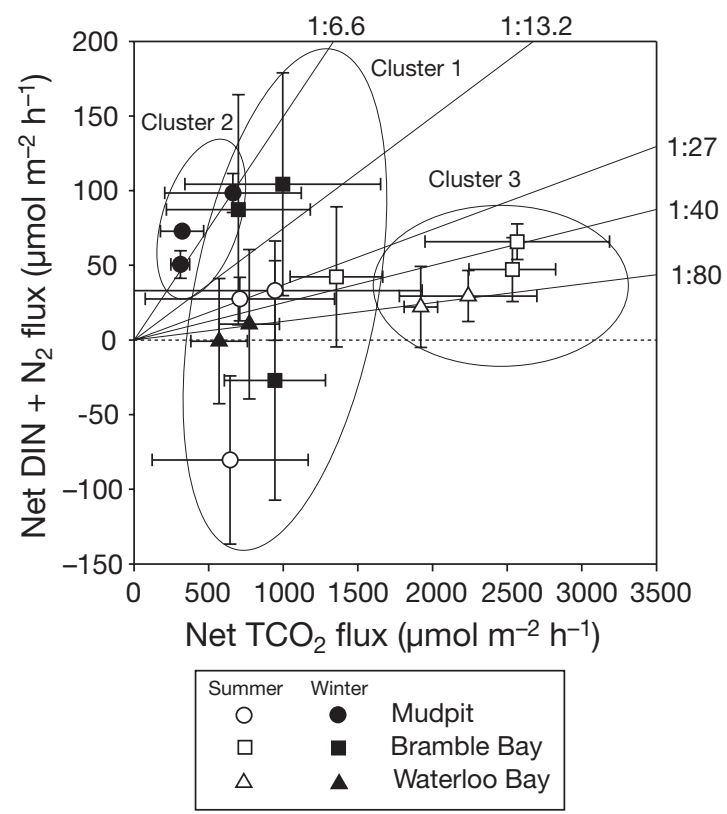

Fig. 7. Relationship between organic carbon mineralisation (indicated by net $\mathrm{TCO}_{2}$ flux: means $\pm \mathrm{SD}$ ) and nitrogen mineralisation (indicated by net DIN $+\mathrm{N}_{2}$ flux: means $\pm \mathrm{SD}$ ). Relatively few points plot within the theoretical range for the mineralisation of Redfield algae (1:6.6 in the absence of calcium carbonate dissolution to $1: 13.2$ in the presence of maximum calcium carbonate dissolution). Sites above 1:6.6 indicate potential effects of bio-irrigation; however, most remain well below 1:13.2, indicating a net retention of nitrogen within the benthos and/or the mineralisation of high $\mathrm{C}: \mathrm{N}$ organic carbon 
gest high bacterial mortality, potentially in response to low OC supply during winter.

$\mathrm{C}: \mathrm{N}$ ratios of fluxes during summer are clearly higher than winter, with averages ranging from 27:1 in the Mudpit to greater than 80:1 in Waterloo Bay (Fig. 7). High flux C:N ratios are commonly observed in shallow sub-tropical systems (Ferguson et al. 2004a, Eyre \& Ferguson 2005) and are generally attributed to either a high C:N substrate and/or $\mathrm{N}$ assimilation by benthic microbes. Cluster 3 sites were all characterised by high sediment $\mathrm{C}: \mathrm{N}$ ratios, suggesting that bacteria may have been degrading a nitrogen-poor substrate, resulting in the assimilation and retention of $\mathrm{N}$ in bacterial biomass, and thereby reducing DIN effluxes (Blackburn 1988, van Duyl et al. 1993). However, as suggested above, phytodetritus may have been an important energy source for benthic metabolism across the study area at this time. While phytodetritus would be expected to have a C:N close to Redfield (see Fig. 6), the heterotrophically mediated release of low C:N DON compounds during the initial mineralisation phase of this material may increase the $\mathrm{C}: \mathrm{N}$ ratio of remaining sediment OC (Newell et al. 1981, Blackburn et al. 1996), thereby promoting $\mathrm{N}$ uptake by bacteria and reducing DIN effluxes. In addition, the biomass of benthic bacterial communities is likely to have increased significantly in response to the deposition of both flood-borne OC and the post-flood phytoplankton bloom (Meyer-Reil 1983). As the OC supply waned following the bloom, the benthos may have become Nlimited as the $\mathrm{C}: \mathrm{N}$ of the substrate increased and mineralisation shifted to the more refractory components of cell detritus. Further, the C:N of DON in porewaters has been shown to increase as OC supply decreases and mineralisation rates decline (Burdige \& Zheng 1998).

Autotrophic DIN assimilation, and/or heterotrophic DIN assimilation in association with autotrophic production, will also raise flux C:N or drive it negative (due to net uptake by the sediments (Ferguson et al. 2004a) (Fig. 7). $\mathrm{O}_{2}$ :DIN flux ratios in western Moreton Bay (study mean 31:1) are similar to other shallow subtropical systems (Eyre \& Ferguson 2005) and temperate systems (Rizzo et al. 1992, Eyre \& Ferguson 2002), but generally higher than deeper aphotic temperate systems (see Ferguson et al. 2004a for a full discussion). Therefore, it would appear that high $\mathrm{O}_{2}$ :DIN flux ratios at broader scales may be associated with autotrophic assimilation. DIN fluxes during this study were strongly associated with autotrophic production and light climate (i.e. assimilation and immobilisation

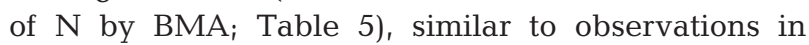
euphotic sediments of both temperate and sub-tropical systems (Blackburn 1988, Rysgaard et al. 2000, Ferguson et al. 2004a). Autotrophic DIN assimilation may therefore account for negative flux $\mathrm{C}: \mathrm{N}$ ratios at some sites (Fig. 7); however, these flux C:N ratios are net diurnal values and should reflect net mineralisation, suggesting that interactions between OC quality and heterotrophic metabolism may also be important controls. It is possible that autotrophic DIN assimilation by BMA may increase the fraction of heterotrophic respiration based on high C:N extracellular OC exudates (Cook et al. 2004). As such, it is likely that both autotrophic and heterotrophic assimilation are controlling DIN fluxes, and that competition for $\mathrm{N}$ substrates (and hence uptake from the water column) increases with light availability (Ferguson et al. 2004a).

\section{DON fluxes}

DON fluxes during this study were similar in magnitude to other shallow sub-tropical and temperate systems (Dollar et al. 1991, Cowan \& Boynton 1996, Burdige \& Zheng 1998, Eyre \& Ferguson 2002, Ferguson et al. 2004a). However, in contrast to most temperate systems, DON fluxes in western Moreton Bay comprised a major fraction (mean $52 \%$ ) of the TDN fluxes (DIN + DON). This is similar to findings for other sub-tropical systems (e.g. Ferguson et al. 2004a, Eyre \& Ferguson, 2005), but much higher than temperate systems such as Chesapeake Bay, where DON fluxes have been found to comprise a smaller faction (3 to $30 \%$ ) of TDN fluxes (Cowan \& Boynton 1996, Burdige \& Zheng 1998). However, these temperate studies were carried out in the dark and therefore did not include interactions between DON and autotrophic processes.

During the present study, light was found to have a significant effect on DON fluxes $(p<0.001)$, with DON effluxes during the day and DON uptake at night. While inconclusive, the PCA shows an equal (not significant) influence of autotrophic and heterotrophic processes over DON flux (Table 2). This result may arise from the co-dependence of processes involved. DON production may be due to the exudation of extracellular organic matter (Goto et al. 1999) and/or the lysis of fresh algae cells by heterotrophic organisms (Bronk et al. 1998). In addition, increases in microbial respiration have been shown to be associated with the increased lysis of bacterial cells by viruses (Glud \& Middelboe 2004). Clear trends in DON fluxes are therefore unlikely, given the overlap of primary driving processes: heterotrophic metabolism is primarily driven by phytodetritus (indicated by $\mathrm{chl} C$, Component 1 ; Table 2) and viable cells in this detritus may contribute significantly to autotrophic production.

The negative association between DIN and DON in Components 1 and 3 indicate that a certain percentage of DON taken up by sediments may be regener- 
ated as DIN (theoretical DIN regeneration $=$ DON: DIN flux; mean $84 \%$ in summer and $512 \%$ in winter). The large return of DIN in winter is most likely due to much smaller DON uptake coupled with excretion of DIN by macrofauna, while the lower summer returns may reflect assimilation and retention of $\mathrm{N}$ by microbes. The predominance of dark DON uptake throughout the study and the association of DON fluxes with Component 1 (Table 2) suggest that heterotrophic organisms were utilising DON compounds as either a carbon or nitrogen substrate (Andersson et al. 2006). Uptake of DON was most pronounced in Cluster 3 (Table 3) and tended to increase during the second half of the night, which suggests that endogenous DON may become depleted within the benthos during the dark, leading microbes to remove dissolved substrates from the water column. Within Cluster 3, dark DON uptake increased as a function of sediment $C: N\left(r^{2}=0.58 ; p<0.001\right)$, suggesting that DON may have been relatively more important as an energy source where sediment solid phase OC was dominated by allochthonous material in the bays adjacent to the Brisbane River mouth.

\section{$\mathbf{N}_{2}$ fluxes}

Net $\mathrm{N}_{2}$ fluxes measured during this study indicate that denitrification rates in western Moreton Bay

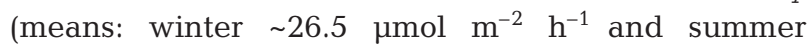
$\sim 6.5 \mu \mathrm{mol} \mathrm{m} \mathrm{m}^{-2} \mathrm{~h}^{-1}$ ) were generally similar to others nearby and to northern hemisphere, sub-tropical estuaries (e.g. Yoon \& Benner 1992, Eyre \& Ferguson 2005), but relatively low when compared with most reported values for temperate systems (e.g. Seitzinger 1987, Herbert 1999). The lower denitrification in sub-tropical systems subject to relatively small, episodic freshwater inputs may reflect an overall positive relationship between the OC supply and denitrification rates postulated to explain global denitrification trends (Middelburg et al. 1996). We observed a significant reduction in $\mathrm{N}_{2}$ flux during summer; however, no consistent seasonal trends in denitrification emerge from the literature for either sub-tropical or temperate systems due to the complex interaction of influencing factors. Summer minima have also been observed in the nearby Brunswick estuary, due primarily to the breakdown of coupled nitrification-denitrification $\left(D_{n}\right)$ during periods of high OC supply (Eyre \& Ferguson 2005). However, high inter-annual variation in $\mathrm{N}_{2}$ fluxes occurred during summer months in this system, resulting in no consistent seasonal signal. Similar inter-annual variation is likely to occur in western Moreton Bay, with the results being heavily influenced by the large flood event preceding the summer sample effort.
The PCA models (Tables $2 \& 5$ ) indicate that heterotrophic metabolism was a primary control on the spatial and temporal variability of net $\mathrm{N}_{2}$ fluxes during this study (e.g. Component 2, Table 5). Reductions in denitrification efficiency (DE $=\mathrm{N}_{2}$ flux $/\left[\mathrm{N}_{2}+\right.$ DIN flux]) with increasing respiration (Cluster $2>1>3$; Table 3) are consistent with observations in other shallow temperate and sub-tropical systems (Eyre \& Ferguson 2005). This trend has been generally attributed to breakdowns in $\mathrm{D}_{\mathrm{n}}$ due to reduced $\mathrm{O}_{2}$ supply with increasing heterotrophic metabolism. Hence, while mean annual denitrification rates may be controlled by OC supply, variation in denitrification across western Moreton Bay may be primarily limited by reductions in $\mathrm{D}_{\mathrm{n}}$. Denitrification measurements using the isotope pairing technique in a nearby bay confirm that $D_{n}$ dominates in this system throughout the year (90\%) due to predominantly low $\mathrm{NO}_{3}{ }^{-}$concentrations in the water column (Ferguson \& Eyre in press.); hence, overall rates are likely to be sensitive to controls over $D_{n}$. The episodic nature of nutrient inputs to Moreton Bay and its shallow morphology result in an efficient transformation of inorganic nitrogen by phytoplankton; hence, organic nitrogen is the major form delivered to the sediments, thereby favouring the $D_{n}$ pathway. This may represent a key difference between sub-tropical systems and systems at other latitudes that are subject to greater seasonal nutrient inputs.

Direct $\mathrm{N}_{2}$ fluxes measured during this study give an indication of net benthic denitrification (Kana et al. 1994) or, specifically, the balance between the 2 dominant biological processes affecting $\mathrm{N}_{2}$ in the benthic environment (i.e. denitrification $-\mathrm{N}$ fixation $=$ net $\mathrm{N}$ flux, assuming insignificant anammox). In some cases during this study, it appeared that $\mathrm{N}$ fixation exceeded denitrification, causing an uptake of $\mathrm{N}_{2}$ by the sediments (e.g. Site MP2 during summer). The implied N fixation rates at Site MP2 (40 to $67 \mu \mathrm{mol} \mathrm{m}{ }^{-2} \mathrm{~h}^{-1}$ ) are high but within the range of rates published for similar sub-tidal unvegetated sediments (Newell et al. 2002) and are consistent with high rates of $\mathrm{N}$ fixation in bare substrates with low OC content adjacent to coral reefs (Shashar et al. 1994). Significant N fixation in mid-bay sediments supports the hypothesis that $\mathrm{N}$ fixation may represent a major $\mathrm{N}$ input to the annual Moreton Bay nutrient budget (Eyre \& Ferguson 2002).

It is difficult to assess the overall effect of $\mathrm{N}$ fixation on the spatial and temporal trends in net $\mathrm{N}_{2}$ fluxes because we have no indicator of diazotrophic activity. It is possible that the significant reduction in $\mathrm{N}_{2}$ fluxes during summer with increasing $\mathrm{chl} c$ (i.e. labile OC), respiration and $\mathrm{RQ}$ is partly due to increased $\mathrm{N}$ fixation by sulphate reducing bacteria, which has been shown to be stimulated by inputs of DOC (Welsh et al. 1996, McGlathery et al. 1998). As discussed above, high flux 
$\mathrm{C}: \mathrm{N}$ ratios in Cluster 3 suggested possible $\mathrm{N}$ limitation, which may stimulate $\mathrm{N}$ fixation in sulphate reducers (Welsh et al. 1996). The significantly higher porewater $\mathrm{NO}_{3}{ }^{-}$concentrations observed during summer contradict this interpretation. We have no explanation for this result; however, we suggest that the measured porewater $\mathrm{NO}_{3}{ }^{-}$may be artificially high due to the inclusion of intracellular compounds lysed from bacterial biomass during filtering (Rysgaard et al. 2000). An in- crease in $\mathrm{N}$ fixation by cyanobacteria is also likely during summer due to higher temperatures (Mulholland \& Capone 1999, Karl et al. 2002).

\section{Summary and synthesis}

The 3 clusters used to classify sediment processes provide a basic conceptual understanding of how
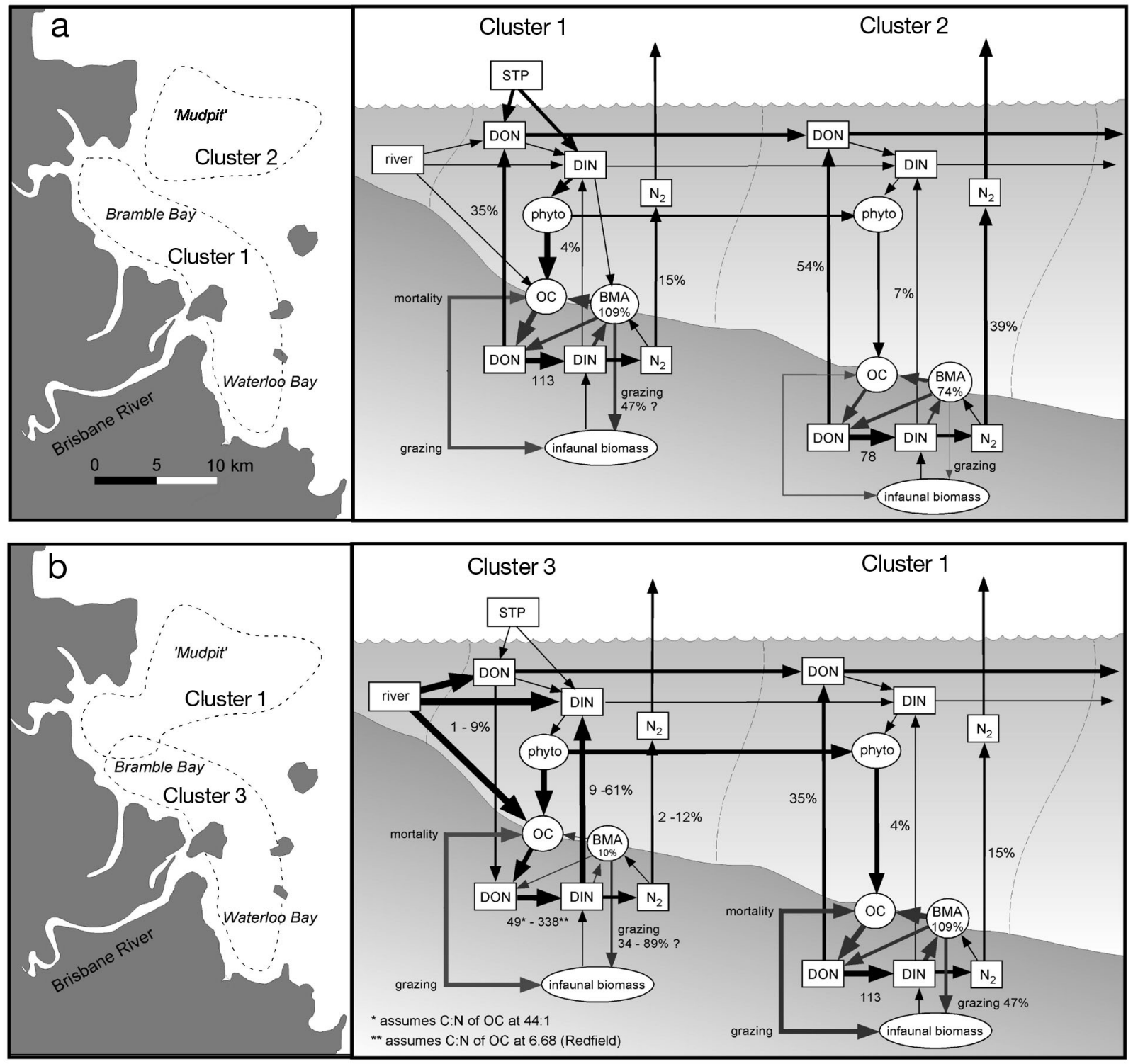

Fig. 8. Conceptual model of benthic metabolism and N cycling in western Moreton Bay: (a) winter scenario; (b) summer post-flood scenario. Clusters represent 3 distinct cycling states during the study. Percentages below the DON to DIN arrows indicate estimated $\mathrm{N}$ mineralisation (in $\mu \mathrm{mol} \mathrm{m} \mathrm{m}^{-2} \mathrm{~h}^{-1}$, see Table 6 for details) accounted for by the different $\mathrm{N}$ fluxes. Due to uncertainties in the $\mathrm{C}: \mathrm{N}$ of $\mathrm{OC}$ undergoing degradation in Cluster 3, 2 values are shown for $\mathrm{N}$ remineralisation based on Redfield C:N and the maximum measured sediment C:N (44:1) in this cluster. (a) Clusters 1 and 2 represent nearshore and offshore sediments, respectively; in winter; (b) post-flood conditions in summer cause a shift from Cluster 1 to Cluster 3 in southern Bramble Bay and Waterloo Bay, and a shift to cluster 1 in the offshore Mudpit sediments. Clusters 1 and 2 most likely represent the predominant condition within western Moreton Bay, highlighting the potential important role of benthic microalgae and DON in the nitrogen cycle of these shallow sub-tropical systems; BMA: benthic microalgae; STP: sewage treatment plant 
benthic metabolism and $\mathrm{N}$ cycling in western Moreton Bay vary spatially and across seasonal and freshwater input (Fig. 8, Tables 3 \& 6). Clusters 1 and 2 most likely represent conditions across the study area for the majority of the time, with benthic metabolism and $\mathrm{N}$ cycling controlled by interactions between light availability (determined by depth and suspended solids), labile OC supply (primarily driven by the supply of phytodetritus) and OC quality. During winter, nearshore sediments are represented by Cluster 1 . These sediments receive a greater labile OC supply from phytoplankton blooms due to their proximity to nutrient inputs from catchment and sewage treatment plant sources. However, the greater light availability in this cluster causes a potentially high turnover (up to $100 \%$ ) of remineralised DIN by BMA, some of which may end up in the DON pool (via both autotrophic and heterotrophic processes), while up to $47 \%$ may be removed by grazing. We hypothesise that the link between infaunal biomass and $\mathrm{OC}$ is dynamic, with periods of biomass increase due to OC carbon inputs and periods of biomass decrease following the waning of OC supply. Sediments further offshore are represented by Cluster 2, which receives smaller labile OC inputs and less light; therefore, respiration and $\mathrm{N}$ remineralisation is lower as is DIN turnover by BMA. Denitrification efficiency is highest in the Cluster 2 sediments. Overall, the makeup of benthic fluxes is similar in these 2 clusters, with DIN fluxes accounting for a relatively small percentage of

Table 6. Relative amount (\%) of the theoretical $\mathrm{N}$ mineralised (calculated from net $\mathrm{TCO}_{2}$ flux) accounted for by different $\mathrm{N}$ fluxes in each cluster. Benthic microalgae (BMA) assimilation of $\mathrm{N}$ is a temporary recycling term; however, it shows the potential importance of this pathway for turning over and modifying remineralised $\mathrm{N}$. Total $\mathrm{N}$ flux indicates the percentage of remineralised $\mathrm{N}$ that can be accounted for by measured fluxes, with the residual accounted for by either grazing of BMA biomass or an over-estimation of remineralised $\mathrm{N}$ due to the mineralisation of higher $\mathrm{C}: \mathrm{N}$ organic carbon (OC) than Redfield. While DON fluxes are not strictly end products of OC mineralisation, they have been included in this simple budget to account for net losses of $\mathrm{N}$ from the sediments

\begin{tabular}{|lccc|}
\hline & \multicolumn{3}{c|}{ Cluster } \\
& 1 & 2 & 3 \\
\hline N mineralisation $^{\mathrm{a}}\left(\mu \mathrm{mol} \mathrm{m}^{-2} \mathrm{~h}^{-1}\right)$ & 113 & 78 & 338 \\
Net DIN flux (\%) & 4 & 7 & 8 \\
Net DON flux (\%) & 35 & 54 & -4 \\
Net $\mathrm{N}_{2}$ flux (\%) & 15 & 39 & 1 \\
Total N flux (\%) & 53 & 100 & 6 \\
BMA assimilation (\%) & 109 & 74 & 10 \\
aN mineralisation estimated from net $\mathrm{TCO}_{2}$ fluxes assum- \\
ing the mineralisation of Redfield OC $(\mathrm{C}: \mathrm{N}=6.6)$ \\
\hline
\end{tabular}

remineralised $\mathrm{N}$ and the bulk accounted for by DON fluxes, followed by $\mathrm{N}_{2}$ fluxes (Table 6). The most marked differences in benthic processes occurred in response to large OC inputs from the flood event and post-flood phytoplankton bloom (i.e. a shift from Cluster 1 to 3 in Bramble and Waterloo Bays). Cluster 3 is characterised by a significant increase in benthic respiration, lower light and uptakes of DON. High flux $\mathrm{C}: \mathrm{N}$ ratios indicated that potential nitrogen limitation of the benthos was developing as OC supply waned following the post-flood bloom. Hence, we hypothesise that the conditions represented by Cluster 3 may be transitory. For the majority of the time, the system is most likely best described by spatial shifts in Clusters 1 and 2 according to seasonal variations in temperature, light, nutrient and freshwater inputs and circulation patterns. These distinct but relatively subtle temporal and spatial shifts in benthic processes contrast with the more dramatic seasonal shifts between autotrophy and heterotrophy observed in tropical and temperate systems that are subject to more sustained freshwater inputs (e.g. Caffery et al. 1998).

The highly episodic nature of inputs to western Moreton Bay indicates a primary role of internal nutrient recycling and sources of bio-available $\mathrm{N}$ other than dissolved inorganic species. The dominant contribution of DON to water column nitrogen and benthic fluxes highlights its potential importance in sub-tropical systems, both as a substrate for microbial growth (Descy et al. 2002, Berman \& Bronk 2003), a source of bio-available $\mathrm{N}$ for autochthonous production (Ferguson et al. 2004b), and a nitrogen sink via the export of refractory compounds (Ogawa et al. 2001). The importance of DON to coastal production has been noted for temperate systems (Seitzinger \& Sanders 1997); however, we hypothesise that DON may be even more pivotal in sub-tropical systems, especially as a recycling term. The makeup and C:N of DON fluxes is largely unknown and therefore warrants further research. Likewise, the apparent influence of $\mathrm{N}$ fixation on net $\mathrm{N}_{2}$ fluxes observed during this study affirms the potential importance of this process in Moreton Bay (Eyre \& McKee 2002).

Acknowledgements. This study was funded by the Redcliffe and Brisbane City Councils, the South East Queensland Regional Water Quality Management Strategy and an ARC Large Grant awarded to B.E. (A00000938). We thank Arthur Webb, Tony Browne and Peter Squire who helped during fieldwork and laboratory analysis. Water quality data was supplied by Queensland Environmental Protection Agency as part of the Ecosystem Health Monitoring Program administered by the Moreton Bay Waterways and Catchments Partnership. 


\section{LITERATURE CITED}

Almgren T, Dryssen D, Fonselius S (1983) Determination of alkalinity and total carbonate. In: Grasshoff K, Ehrnhardt M, Kremling K (eds) Methods of seawater analysis. Verlag Chemie, Weinheim, p 99-123

Anderson LG, Hall POJ, Iverfeldt A, Rutgers van der Loeff MM, Sundby I, Westerlund SFG (1986) Benthic respiration measured by total carbonate production. Limnol Oceanogr 31:319-329

Andersson MGI, van Rijswijk P, Middelburg JJ (2006) Uptake of dissolved inorganic nitrogen, urea and amino acids in the Scheldt estuary: comparison of organic carbon and nitrogen uptake. Aquat Microb Ecol 44:303-315

Asmus RM, Jensen MH, Jensen KM, Kristensen E, Asmus H, Wille A (1998) The role of water movement and spatial scaling for the measurement of dissolved inorganic nitrogen fluxes in intertdal sediments. Estuar Coast Shelf Sci 46:221-232

Berelson W, Heggie D, Longmore A, Kilgore T, Nicholson G, Skyring G (1998) Benthic nutrient recycling in Port Phillip Bay, Australia. Estuar Coast Shelf Sci 46:917-934

Berman T, Bronk DA (2003) Dissolved organic nitrogen: a dynamic participant in aquatic ecosystems. Aquat Microb Ecol 31:279-305

Bianchi TS, Dawson R, Sawangwong P (1988) The effects of macrobenthic deposit-feeding on the degradation of chloropigments in sandy sediments. J Exp Mar Biol Ecol 122:243-255

Billen G, Lancelot C (1988) Modelling benthic nitrogen cycling in temperate coastal ecosystems. In: Blackburn TH, Sørensen J (eds) Nitrogen cycling in coastal marine environments, Vol 33. John Wiley \& Sons, Chichester, p 341-378

Bird FL, Ford PW, Hancock GJ (1999) Effect of burrowing macrobenthos on the flux of dissolved substances across the water-sediment interface. Mar Freshw Res 50:523-532

Blackburn TH (1988) Benthic mineralization and bacterial production. In: Blackburn TH, Sørensen J (eds) Nitrogen cycling in coastal marine environments, Vol 33. John Wiley \& Sons, Chichester, p 175-206

Blackburn TH, Hall POJ, Hulth S, Landen A (1996) Organic$\mathrm{N}$ loss by efflux and burial associated with a low efflux of inorganic $\mathrm{N}$ and with nitrate assimilation in Arctic sediments (Svalbard, Norway). Mar Ecol Prog Ser 141: 283-293

Bonsdorff E, Blomqvist EM, Mattila J, Norkko A (1997) Coastal eutrophication: causes, consequences and perspectives in the archipelago areas of the northern Baltic Sea. Estuar Coast Shelf Sci 44:63-72

Boon AR, Duineveld GCA, Kok A (1999) Benthic organic matter supply and metabolism at depositional and non-depositional areas in the North Sea. Estuar Coast Shelf Sci 49: 747-761

Boynton WR, Kemp WM, Keefe CW (1982) A comparative analysis of nutrients and other factors influencing estuarine phytoplankton production. Academic Press, New York

Boynton WR, Garber JH, Summers R, Kemp WM (1995) Inputs, transformations, and transport of nitrogen and phosphorus in Chesapeake Bay and selected estuaries. Estuaries 18:285-314

Bronk DA, Glibert PM, Malone TC, Banahan S, Sahlsten E (1998) Inorganic and organic nitrogen cycling in Chesapeake Bay: autotrophic versus heterotrophic processes and relationships to carbon flux. Aquat Microb Ecol 15: 177-189

Brotas V, Plante-Cuny MR (1998) Spatial and temporal pat- terns of microphytobenthic taxa of estuarine tidal flats in the Tagus Estuary (Portugal) using pigment analysis by HPLC. Mar Ecol Prog Ser 171:43-51

Burdige DJ, Zheng S (1998) The biochemical cycling of dissolved organic nitrogen in estuarine sediments. Limnol Oceanogr 43:1796-1813

Cadee GC, Hegeman J (1977) Distribution of primary production of the benthic microflora and accumulation of organic matter on a tidal flat area, Balgzand, Dutch Wadden Sea. Neth J Sea Res 11:24-41

Caffrey JM, Cloern JE, Grenz C (1998) Changes in production and respiration during a spring phytoplankton bloom in San Francisco Bay, California, USA: implications for net ecosystem metabolism. Mar Ecol Prog Ser 172:1-12

Cahoon LB, Beretich GR, Thomas CJ, McDonald AM (1993) Benthic microalgal production at Stellwagen Bank, Massachusetts Bay, USA. Mar Ecol Prog Ser 102:179-185

Cloern JE (2001) Our evolving conceptual model of the coastal eutrophication problem. Mar Ecol Prog Ser 210: 223-253

Colijn F, de Jonge VN (1984) Primary production of microphytobenthos in the Ems-Dollard estuary. Mar Ecol Prog Ser 14:185-196

Cook PLM, Revill AT, Clementson LA, Volkman JK (2004) Carbon and nitrogen cycling on intertidal mudflats of a temperate Australian estuary. III. Sources of organic matter. Mar Ecol Prog Ser 280:55-72

Cowan JLW, Boynton WR (1996) Sediment-water oxygen and nutrient exchanges along the longitudinal axis of Chesapeake Bay: seasonal patterns, controlling factors and ecological significance. Estuaries 19:562-580

Cowan JLW, Pennock JR, Boynton WR (1996) Seasonal and interannual patterns of sediment-water nutrient and oxygen fluxes in Mobile Bay, Alabama (USA): regulating factors and ecological significance. Mar Ecol Prog Ser 141: 229-245

Dennison WC, Abal EG (1999) Moreton Bay Study: a scientific basis for the healthy waterways campaign. South East Queensland Regional Water Quality Management Strategy, Brisbane

Descy JP, Leporcq B, Viroux L, Francois C, Servais P (2002) Phytoplankton production, exudation and bacterial reassimilation in the River Meuse (Belgium). J Plankton Res 24:161-166

Dollar SJ, Smith SV, Vink SM, Obrebski S, Hollibaugh JT (1991) Annual cycle of benthic nutrient fluxes in Tomales Bay, California, and contribution of the benthos to total ecosystem metabolism. Mar Ecol Prog Ser 79:115-125

Dong LF, Thornton DCO, Nedwell DB, Underwood GJC (2000) Denitrification in sediments of the River Colne estuary, England. Mar Ecol Prog Ser 203:109-122

Eyre BD (1995) A first-order nutrient budget for the tropical Moresby estuary and catchment North Queensland, Australia. J Coastal Res 11:717-732

Eyre BD (2000) Regional evaluation of nutrient transformation and phytoplankton growth in nine river-dominated subtropical east Australian estuaries. Mar Ecol Prog Ser 205: 61-83

Eyre BD, Ferguson AJP (2002) Comparison of carbon production and decomposition, benthic nutrient fluxes and denitrification in seagrass, phytoplankton, benthic microalgaeand macroalgae-dominated warm-temperate Australian lagoons. Mar Ecol Prog Ser 229:43-59

Eyre BD, Ferguson AJP (2005) Benthic metabolism and nitrogen cycling in a sub-tropical east Australian estuary (Brunswick): temporal variability and controlling factors. Limnol Oceanogr 50:81-96 
Eyre BD, McKee LJ (2002) Carbon, nitrogen and phosphorus budgets for a shallow sub-tropical coastal embayment (Moreton Bay, Australia). Limnol Oceanogr 47(4): 1043-1055

Eyre BD, Rysgaard S, Dalsgaard T, Christensen PB (2002) Comparison of isotope pairing and $\mathrm{N}_{2} / \mathrm{Ar}$ methods for measuring sediment denitrification - assumptions, modifications and implications. Estuaries 25:1077-1087

Ferguson AJP, Eyre BD (in press) Seasonal discrepancies in dentrification measured by isotope pairing and $\mathrm{N}_{2}: \mathrm{Ar}$ techniques. Mar Ecol Prog Ser

Ferguson AJP, Eyre BD, Gay JM (2003) Organic matter and benthic metabolism in euphotic sediments along shallow sub-tropical estuaries, northern NSW, Australia. Aquat Microb Ecol 33:137-154

Ferguson AJP, Eyre BD, Gay JM (2004a) Benthic nutrient fluxes in euphotic sediments along shallow sub-tropical estuaries, northern NSW, Australia. Aquat Microb Ecol 37: 219-235

Ferguson AJP, Eyre BD, Gay JM (2004b) Nutrient cycling in the sub-tropical Brunswick estuary, Australia. Estuaries 27:1-17

Giblin AE, Hopkinson CS, Tucker J (1997) Benthic metabolism and nutrient cycling in Boston Harbor, Massachusetts. Estuaries 20:346-364

Glibert PM (1993) The interdependence of uptake and release of $\mathrm{NH}_{4}{ }^{+}$and organic nitrogen. Mar Microb Food Webs 7:53-67

Glud RN, Middelboe M (2004) Virus and bacterial dynamics of a coastal sediment: implications for benthic carbon cycling. Limnol Oceanogr 49:2071-2081

Goto N, Kawamura T, Mitamura O, Terai H (1999) Importance of extracellular organic carbon production in the total primary production by tidal-flat diatoms in comparison to phytoplankton. Mar Ecol Prog Ser 190:289-295

Guldberg LB, Finster K, Jørgensen NOG, Middelboe M, Lomstein BA (2002) Utilization of marine sedimentary dissolved organic nitrogen by native anaerobic bacteria. Limnol Oceanogr 47:1712-1722

Herbert RA (1999) Nitrogen cycling in coastal marine ecosystems. FEMS Microbiol Rev 23:563-590

Hopkinson CS, Giblin AE, Tucker J, Garrit RH (1999) Benthic metabolism and nutrient cycling along an estuarine salinity gradient. Estuaries 22:863-881

Howarth RW (1984) The ecological significance of sulfur in the energy dynamics of saltmarsh and coastal sediments. Biogeochemistry 1:5-27

Jeffrey SW, Welschmeyer NA (1997) Spectrophotometric and fluorometric equations in common use in oceanography. In: Jeffrey SW, Mantoura RFC, Wright SW (eds) Phytoplankton pigments in oceanography: guidelines to modern methods. UNESCO, Paris, p 597-615

Jørgensen BB (1982) Mineralization of organic matter in the sea bed - the role of sulfate reduction. Nature 296

Jørgensen BB (1996) Material flux in the sediment. In: Jørgensen BB, Richardson K (eds) Eutrophication in coastal marine ecosystems, Vol 52. American Geophysical Union, Washington, p 115-135

Kana TM, Darkangelo C, Hunt MD, Oldam JB, Bennett GE, Cornwell JC (1994) Membrane inlet mass spectrometer for rapid high-precision determination of $\mathrm{N}_{2}, \mathrm{O}_{2}$, and $\mathrm{Ar}$ in environmental samples. Anal Chem 66:4166-4170

Karl D, Michaels A, Bergman B, Capone D and 6 others (2002) Dinitrogen fixation in the world's oceans. Biogeochemisttry 57/58:47-98

Kiørboe T (1996) Material flux in the water column. In: Jørgensen BB, Richardson K (eds) Eutrophication in coastal marine ecosystems, Vol 52. American Geophysical Union, Washington, p 67-94

Koster M, Meyer-Reil LA (2001) Characterisation of carbon and microbial biomass pools in shallow water coastal sediments of the southern Baltic Sea (Nordrugensche Bodden). Mar Ecol Prog Ser 214:25-41

Kristensen E, Jensen MH, Aller RC (1991) Direct measurement of dissolved inorganic nitrogen exchange and denitrification in individual polychaete (Nereis virens) burrows. J Mar Res 49:355-377

Kristensen E, Jensen MH, Jensen KM (1997) Temporal variations in microbenthic metabolism and inorganic nitrogen fluxes in sandy and muddy sediments of a tidally dominated bay in the northern Wadden Sea. Helgol Meeresunters 51:295-320

Lancelot C, Billen G (1985) Carbon-nitrogen relationships in nutrient metabolism of coastal marine ecosystems. In: Jannasch HW, Williams Pl (eds) Advances in aquatic microbiology, Vol 3. Academic Press, London, p 263-321

MacIntyre HL, Geider RJ, Miller DC (1996) Microphytobenthos: the ecological role of the 'Secret Garden' of unvegetated, shallow-water marine habitats. 1. Distribution, abundance and primary production. Estuaries 19:186-201

Mackin JE, Swider KT (1989) Organic matter decomposition pathways and oxygen consumption in coastal marine sediments. J Mar Res 47:681-716

Marcus NH, Boero F (1998) Minireview: the importance of benthic-pelagic coupling and the forgotten role of life cycles in coastal aquatic systems. Limnol Oceanogr 43: 763-768

McGlathery KJ, Risgaard-Petersen N, Christensen PB (1998) Temporal and spatial variation in nitrogen fixation activity in the eelgrass Zostera marina rhizosphere. Mar Ecol Prog Ser 168:245-258

Meyercordt J, Meyer-Reil LA (1999) Primary production of benthic microalgae in two shallow coastal lagoons of different trophic status in the southern Baltic Sea. Mar Ecol Prog Ser 178:179-191

Meyer-Reil LA (1983) Benthic response to sedimentation events during autumn to spring at a shallow water station in the Western Kiel Bight. Mar Biol 77:247-256

Middelburg JJ, Soetaert K, Herman PMJ, Heip CHR (1996) Denitrification in marine sediments: a model study. Global Biogeochem Cycles 10:661-673

Miller-Way T, Boland GS, Rowe GT, Twilley RR (1994) Sediment oxygen consumption and benthic nutrient fluxes on the Louisiana continental shelf: a methodological comparison. Estuaries 17:809-815

Mulholland MR, Capone DG (1999) Nitrogen fixation, uptake and metabolism in natural and cultured populations of Trichodesmium spp. Mar Ecol Prog Ser 188:33-49

Newell RC, Lucas MI, Linley EAS (1981) Rate of degradation and efficiency of conversion of phytoplankton debris by marine micro-organisms. Mar Ecol Prog Ser 6:123-136

Newell RIE, Cornwell JC, Owens MS (2002) Influence of simulated bivlve biodeposition and microphytobenthos on sediment nitrogen dynamics: a laboratory study. Limnol Oceanogr 47:1367-1379

Ogawa H, Amagai Y, Koike I, Kaiser K, Benner R (2001) Production of refractory dissolved organic matter by bacteria. Science 292:917-920

Redfield AC (1934) On the proportions of organic derivatives in seawater - their relation to the composition of plankton. Liverpool University Press, Liverpool

Rizzo WM, Wetzel RL (1985) Intertidal and shoal benthic community metabolism in a temperate estuary: studies of spatial and temporal scales of variability. Estuaries 8:342-351 
Rizzo WM, Lackey GJ, Christian RR (1992) Significance of euphotic, subtidal sediments to oxygen and nutrient cycling in a temperate estuary. Mar Ecol Prog Ser 86:51-61

Rysgaard S, Christensen PB, Sørensen MV, Funch P, Berg P (2000) Marine meiofauna, carbon and nitrogen mineralisation in sandy and soft sediments of Disko Bay, West Greenland. Aquat Microb Ecol 21:59-71

Sampou P, Oviatt CA (1991) A carbon budget for a eutrophic marine ecosystem and the role of sulfur metabolism in sedimentary carbon, oxygen and energy dynamics. J Mar Res 49:825-844

Schreiber RA, Pennock JR (1995) The relative contribution of benthic microalgal production to total microalgal production in a shallow sub-tidal estuarine environment. Ophelia 42:335-352

Seitzinger SP (1987) Nitrogen biogeochemistry in an unpolluted estuary. The importance of benthic denitrification. Mar Ecol Prog Ser 41:177-186

Seitzinger SP, Sanders RW (1997) Contribution of dissolved organic nitrogen from rivers to estuarine eutrophication. Mar Ecol Prog Ser 159:1-12

Shashar N, Feldstein T, Cohen Y, Loya Y (1994) Nitrogen fixation (acetylene reduction) on a coral reef. Coral Reefs 13: 171-174

Stumm W, Morgan JJ (1996) Aquatic chemistry: chemical

Editorial responsibility: Antje Boetius,

Bremen, Germany equilibria and rates in natural waters. John Wiley \& Sons, New York

Valderamma JC (1981) The simultaneous analysis of TP and TN in natural waters. Mar Chem 10:109-122

van Duyl FC, van Raaphorst W, Kop AJ (1993) Benthic bacterial production and nutrient sediment-water exchange in sandy North Sea sediments. Mar Ecol Prog Ser 100:85-95

Welsh DT, Bourgues S, de Wit R, Herbert RA (1996) Seasonal variations in nitrogen-fixation (acetylene reduction) and sulphate-reduction rates in the rhizosphere of Zostera noltii: nitrogen fixation by sulphate-reducing bacteria. Mar Biol 125:619-628

Wheeler PA, Kirchman DL (1986) Utilisation of inorganic and organic nitrogen by bacteria in marine systems. Limnol Oceanogr 31:998-1009

Yamada H, Kayama M (1987) Liberation of nitrogenous compounds from bottom sediments and effect of bioturbation by small bivalve, Theora lata (Hinds). Estuar Coast Shelf Sci 24:539-555

Yoon WB, Benner R (1992) Denitrification and oxygen consumption in sediments of two south Texas estuaries. Mar Ecol Prog Ser 90:157-167

Zimmerman AR, Benner R (1994) Denitrification, nutrient regeneration and carbon mineralization in sediments of Galveston Bay, Texas, USA. Mar Ecol Prog Ser 114:275-288

Submitted: October 4, 2006; Accepted: May 22, 2007

Proofs received from author(s): July 3, 2007 